\title{
Influence of coastal upwelling-downwelling variability on tropical euphausiid abundance and community structure in the inshore Mexican central Pacific
}

\author{
Israel Ambriz-Arreola ${ }^{1, *}$, Jaime Gómez-Gutiérrez ${ }^{2}$, \\ María del Carmen Franco-Gordo ${ }^{1}$, Bertha E. Lavaniegos ${ }^{3}$, Enrique Godínez-Domínguez ${ }^{1}$ \\ ${ }^{1}$ Centro de Ecología Costera, Universidad de Guadalajara, Gómez Farias 82, San Patricio Melaque, Jalisco 48980, Mexico \\ ${ }^{2}$ Centro Interdisciplinario de Ciencias Marinas, Departamento de Plancton y Ecología Marina, Ave. IPN s/n, \\ Col. Playa Palo de Santa Rita, Apdo. Postal 592 La Paz, Baja California Sur, CP 23096, Mexico \\ ${ }^{3}$ Departamento de Oceanografía Biológica, Centro de Investigación Científica y de Educación Superior de Ensenada, \\ Km 107 Carretera Tijuana-Ensenada, Apdo. Postal 360, CP 22860, Ensenada, Baja California, Mexico
}

\begin{abstract}
The effect of wind-induced coastal upwellings on tropical euphausiid abundance and community structure was investigated in the Mexican central Pacific $\left(19^{\circ} \mathrm{N}, 105^{\circ} \mathrm{W}\right)$ during a monthly time series (1996-1998). Eight species were identified, of which Euphausia distinguenda contributed between 88 and $90 \%$ of the total euphausiid abundance, and E. lamelligera contributed $\sim 7 \%$. The hydrographic structure (<200 m depth) and euphausiid species composition had strong seasonality patterns associated with the upwelling (February to May) and downwelling (July to November) periods. Redundancy analysis of euphausiid abundance and community structure as a function of the environmental variables revealed that coastal upwelling index, salinity at $10 \mathrm{~m}$ depth, and temperature explained most of the euphausiid abundance variability. Stations sampled during intense upwelling periods had the highest abundance of $E$. distinguenda and $E$. lamelligera juveniles and adults. Their abundance was strongly and positively correlated with salinity and abundance of nano- and microphytoplankton, but was negatively correlated with surface temperature. Larvae of E. distinguenda and the oceanic species Nematoscelis gracilis (downwelling ensemble) were strongly associated with warm waters of low phytoplankton abundance. The hepato-somatic index (ratio of hepatopancreas length to carapace length) of $E$. distinguenda and E. lamelligera adults was significantly larger during mixed and semi-mixed than during stratified periods, providing a useful proxy for euphausiid health and trophic condition. Wind-induced upwelling-downwelling are significant coastal processes that influenced seasonal euphausiid abundance and species composition in this tropical ecosystem, while the strong and brief El Niño event of 1997-98 had only a relatively moderate effect in comparison with that observed on euphausiids from transitional (northwest of Mexico) and temperate (Pacific USA) ecosystems.
\end{abstract}

KEY WORDS: Tropical euphausiids · Euphausia distinguenda · Euphausia lamelligera · Upwelling · Downwelling $\cdot$ El Niño $\cdot$ Mexican central Pacific

\section{INTRODUCTION}

The interaction of northwestern winds, coastline orientation, bottom topography, and regional current system induce coastal upwelling-downwelling events along the central Pacific coast of Mexico, commonly known as the Cabo Corrientes region (Roden 1964, Torres-Orozco et al. 2005, López Sandoval et al. $2009 a, b)$. In this tropical region, upwelling events typically occur from December to May, and are the 
main oceanographic processes producing seasonal variability in phytoplankton photosynthetic pigments (Álvarez-Borrego 1983). Satellite ocean surface chlorophyll a ( chl a) images and in situ chl a concentration measurements show that the coastal region off Cabo Corrientes exhibits strong seasonal variability (López Sandoval et al. 2009a,b). Satellite images of sea-surface temperature in the region show that the influence of upwelling events can extend about $46 \mathrm{~km}$ along the coast, covering an area of approximately $2586 \mathrm{~km}^{2}$ (Torres-Orozco et al. 2005). The effects of these meso-scale coastal features in Cabo Corrientes on zooplankton have been studied for tropical copepods (Suárez-Morales et al. 2000), ichthyoplankton (Franco-Gordo et al. 2002, 2004, León-Chávez et al. 2010), and euphausiids (krill; Sánchez-Osuna \& Hendrickx 1983, Färber-Lorda et al. 2010).

The dominant ocean circulation pattern in the Mexican central Pacific is highly variable and complex, due to the influence of the California Current, Mexican Coastal Current, and currents not easily delimited in the mouth of the Gulf of California (Wyrtki 1967, Baumgartner \& Christensen 1985, Kessler 2006). The Eastern Tropical Pacific (ETP) off Mexico $\left(23\right.$ to $\left.17^{\circ} \mathrm{N}\right)$ has a dynamic circulation characterized by substantial variability forced by atmosphere-ocean interactions at 3 main time-space scales: (1) a poleward coastal current developing during late spring and summer, while an equatorward current is observed during the rest of the year, causing significant seasonal variability in oceanographic conditions; (2) eddies, filaments, and upwelling events that cause intense mesoscale oceanographic activity over days, weeks, or even a few months; (3) the El Niño Southern Oscillation (ENSO) cycle that causes interannual variability inducing anticyclonic (cyclonic) Pacific Ocean circulation during El Niño (La Niña), and (4) high precipitation rates that occur in the Cabo Corrientes region during summer (Lavín et al. 2006, Godínez et al. 2010, MartínezFlores et al. 2011). The Cabo Corrientes region is also influenced by a shallow oxygen minimum zone $\left(<40 \mathrm{~m}\right.$ depth, $<1 \mathrm{ml} \mathrm{O}_{2} \mathrm{l}^{-1}$ ) characterizing the Tropical Surface Water $\left(<30 \mathrm{~m}_{\text {; }}\right.$ also known as Equatorial Surface Water) with relatively high temperature $\left(\geq 18^{\circ} \mathrm{C}\right)$ and low salinity $(<34.9)$, and the Subtropical Subsurface Water with low temperature $\left(\leq 18^{\circ} \mathrm{C}\right)$ and high salinity (Wyrtki 1967, Filonov \& Tereshchenko 2000, Cepeda-Morales et al. 2009).

In the Cabo Corrientes region, a conspicuous seasonal hydrographic cycle prevails that influences phytoplankton biomass and plankton community structure. During the intense upwelling period (February to May), high chl a concentrations and primary productivity rates typically predominate, followed by a transitional upwelling relaxation period (June) and water column stratified conditions (July to December) when the lowest chl a concentrations and primary productivity rates typically occur (López Sandoval et al. 2009a,b).

Upwelling-downwelling pulses should play a significant role in the near-shore hydrographic conditions, plankton abundance, and community structure off Cabo Corrientes, as has been observed in highly productive temperate and transitional coastal windinduced upwelling regions (Huyer 1983, Dorman et al. 2005, Gómez-Gutiérrez et al. 2005, Keister et al. 2005, 2009). A systematic zooplankton time series (December 1995 to December 1998) carried out in the Mexican central Pacific documented the effect of coastal upwelling events on zooplankton biomass and ichthyoplankton assemblage structure (FrancoGordo et al. 2002, 2004). Previous krill studies in the ETP have been realized from single oceanographic cruises (Brinton 1979, Färber-Lorda et al. 1994, 2010, Gómez-Gutiérrez \& Hernández-Trujillo 1994). Relatively more extensive studies about euphausiid biology and ecology have been performed on both sides of the Baja California peninsula (Brinton 1962, 1981, Brinton \& Townsend 1980, 2003, Brinton et al. 1986, Lavaniegos 1994, Gómez-Gutiérrez et al. 1995, Lavaniegos \& Ambriz-Arreola in press).

We studied tropical krill because it is relatively unknown whether their abundance is important to the regional pelagic food web and because the tropical zoogeographic component of zooplankton distributed in Mexican waters has been historically less studied than the west coast of Baja California and the Gulf of California, where temperate and subtropical krill fauna are distributed (Fernández-Álamo \& Färber-Lorda 2006, Gómez-Gutiérrez et al. 2009). Euphausia lamelligera is the numerically dominant krill species in the tropical coastal habitat, and typically E. eximia, E. distinguenda, and E. tenera are the dominant krill species offshore (Färber-Lorda et al. 2010). Adults of these tropical euphausiids are opportunistic omnivores, able to switch diet type in response to changing trophic conditions, while larval stages feed on phytoplankton and microzooplankton (Mauchline \& Fisher 1969). The depth of the oxygen minimum zone shapes the euphausiid daily vertical distribution and their zoogeographic affinities in the ETP region (Brinton 1979). Only 5 oceanographic surveys have been carried out in the mouth of the Gulf of California (including Cabo Corrientes) to 
study euphausiid distribution, abundance, and community structure (Brinton 1962, 1979, SánchezOsuna \& Hendrickx 1983, Gómez-Gutiérrez \& Hernández-Trujillo 1994, Färber-Lorda et al. 2010). Thus, the seasonal and interannual changes in tropical euphausiid abundance and community structure are so far unknown. A zooplankton time series is likely the best sampling strategy to understand the effect of upwelling-downwelling dynamics and other oceanographic and climatic events influencing euphausiids and other zooplankton taxa. However, it is currently recognized that few time series are available for tropical ecosystems (Mackas \& Beaugrand 2010). Multiple zooplankton time series have documented phenology, seasonal, interannual, and longterm environmental effects on the euphausiid community structure from Canada $\left(49^{\circ} \mathrm{N}\right.$ : Mackas et al. 2001, Mackas \& Galbraith 2002), Oregon, USA $\left(45^{\circ} \mathrm{N}\right.$ : Peterson et al. 2002, Feinberg \& Peterson 2003, Gómez-Gutiérrez et al. 2005, Keister et al. 2005), Monterey Bay, California, USA (36 N: Marinovic et al. 2002, Dorman et al. 2005), and California to the Baja California region (38-26 N: Brinton 1981, Brinton \& Townsend 2003). Färber-Lorda et al. (2010) recognized the need for a seasonal study of euphausiid distribution and abundance to elucidate the mechanisms controlling their populations in this tropical ecosystem.

Here we reanalyzed monthly samples from a 1996 to 1998 time series of zooplankton samples, originally collected for a zooplankton biomass and ichthyoplankton study (Franco-Gordo et al. 2002, 2004), in order to investigate the effect of environmental conditions on tropical euphausiid abundance and community structure along the inshore Mexican central Pacific (southern Cabo Corrientes region, $19^{\circ} \mathrm{N}$, $\left.105^{\circ} \mathrm{W}\right)$. We propose that seasonal upwelling processes induce relatively high biomass and productivity in the tropical Cabo Corrientes ecosystem, as has been documented in transitional and temperate ecosystems. The goals of this study were (1) to test the hypothesis that abundance of tropical plankton (phytoplankton assemblages) and euphausiid abundance and community structure are strongly associated with variability in coastal upwelling intensity at a seasonal time scale in the southern Cabo Corrientes region, and (2) to investigate the response of the tropical euphausiid community to a strong, but relatively brief, El Niño event that occurred during 1997-98. Thus, this study will provide an initial baseline on the effect of seasonal environmental conditions and interannual variability imposed by an El Niño event on tropical euphausiid species.

\section{MATERIALS AND METHODS}

\section{Study area and sample collection}

Six oceanographic stations, located along the coasts of Jalisco and Colima states, Mexico $\left(19^{\circ} \mathrm{N}\right.$, $\left.105^{\circ} \mathrm{W}\right)$, were sampled approximately every month between January 1996 and December 1998 (Fig. 1). Oceanographic stations were $3 \mathrm{~km}$ apart and located $<5 \mathrm{~km}$ from the coast where the seafloor depth was between 100 and $130 \mathrm{~m}$. Standard conductivity, temperature, and depth (CTD, Seabird SB09) measurements were made $\sim 10 \mathrm{~m}$ above the seafloor. Seawater samples were collected at $10 \mathrm{~m}$ depth every month during 1998 only, using 51 Niskin bottles to record phytoplankton cell abundance and taxonomic composition.

In total, 146 zooplankton samples were collected during 26 oceanographic cruises using a standard Bongo net (61 cm diameter, $505 \mu \mathrm{m}$ mesh) towed obliquely at 0.4 to $0.5 \mathrm{~m} \mathrm{~s}^{-1}$ from $10 \mathrm{~m}$ above the sea bottom at shallow stations to the surface. Calibrated digital flowmeters installed in the mouth of each net were used to calculate the filtered seawater volume (Smith \& Richardson 1977). All the zooplankton samples were preserved in $4 \%$ formalin saturated with sodium borate. The 1996-98 time series had several gaps in oceanographic cruises caused by climatic (hurricane season) or other logistical problems (August, September 1996; April, May, June, October,

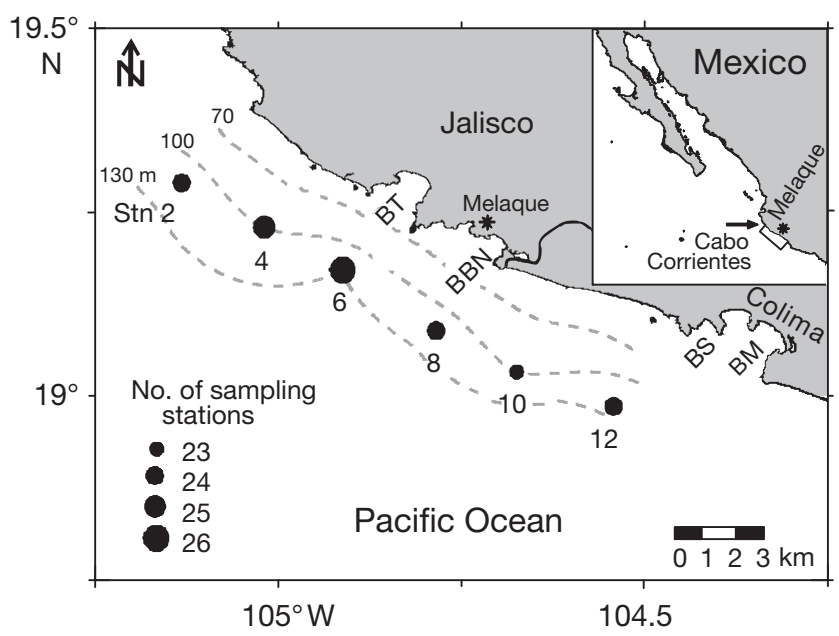

Fig. 1. Study area located along the southwest coast off Cabo Corrientes, showing the nighttime sampling stations located along the coast of Jalisco and Colima, Mexico. Circle sizes are proportional to the number of oceanographic stations sampled between January 1996 and December 1998. BT: Bahía Tenacatita, BBN: Bahía Barra de Navidad, BS: Bahía Santiago, BM: Bahía Manzanillo 
November 1997; and February, October, November 1998). All zooplankton samples were collected at night $(20: 00$ to $07: 00 \mathrm{~h})$ on board the RV 'BIP-V', owned by the Universidad de Guadalajara.

\section{Laboratory analysis}

Each $5 \mathrm{ml}$ phytoplankton sample collected at $10 \mathrm{~m}$ depth was sedimented for $>24 \mathrm{~h}$ to identify and count phytoplankton species using an inverted phasecontrast microscope using the standard Utermöhl technique (Hasle 1978). Nano- and microphytoplankton, consisting mainly of diatoms and dinoflagellates $>5 \mu \mathrm{m}$, were identified using several taxonomic keys (Cupp 1943, Sournia 1967, Saunders \& Glenn 1969, Steidinger \& Williams 1970, LiceaDurán 1974, Taylor 1976, Pesantes 1978, Sournia et al. 1979), and their abundances were standardized (cells $1000 \mathrm{ml}^{-1}$ ).

Euphausiid species were separated from the samples, counted, and identified following standard taxonomic keys (Brinton 1996, Brinton et al. 2000). Most of the adult euphausiids were counted and identified from the complete zooplankton sample, while larvae (calyptopis and furcilia) and juveniles were separated and identified to species level from one-half, one-quarter, or one-eighth aliquots of the original sample. Euphausiid abundance was standardized to ind. $1000 \mathrm{~m}^{-3}$. At least 30 adults from the 2 most abundant species (Euphausia distinguenda and E. lamelligera) collected from each oceanographic station were selected for morphometric measurements. In total, 1063 specimens of E. distinguenda and 503 of E. lamelligera were sexed and measured for total length (TL, from the forward rim of the carapace to the distal end of the telson), carapace length ( $\mathrm{CL}$, from the base forward rim of the carapace to the posterior notch of the carapace), and the length of the hepatopancreas $(\mathrm{HL}$, the longest length from the anterior to the posterior part of the hepatopancreas), also known as the digestive gland. The hepato-somatic index (HSI), defined as the ratio of $\mathrm{HL}$ to $\mathrm{CL}$, is a valuable proxy to infer health and recent trophic conditions. We assumed that a small HSI indicates unfavorable feeding conditions and a large HSI indicates relatively favorable feeding conditions at a seasonal time scale (Shin 2000, Nicol et al. 2004, Virtue et al. 2010, O'Brien et al. 2011). All morphometric measurements were made with a calibrated ocular micrometer of a Carl Zeiss Discovery stereomicroscope $($ precision $=0.1 \mathrm{~mm})$.

\section{Data analysis}

The biological variables analyzed were abundance of phytoplankton (cells $\mathrm{l}^{-1}$ ) and euphausiid species (larvae and postlarvae, ind. $1000 \mathrm{~m}^{-3}$ ). Phytoplankton and euphausiid abundance were explored to detect outliers and later log transformed $\left(\log _{10}[x+1]\right)$ for statistical analysis (see Fig. 3). A 1-way analysis of variance (ANOVA) was done to test whether significant differences exist in phytoplankton and euphausiid abundances among climatic periods defined during our study: semi-mixed (transitional), mixed (upwelling), and stratified (downwelling). A similar 1-way ANOVA was performed using the euphausiid HSI to detect differences among the same environmental condition periods. If an ANOVA was significant $(\alpha<$ 0.05 ) for any of the variables tested, a Tukey's post hoc test was carried out to define the specific sampling unit that was significantly distinct from the others. Simple linear regression was used to test the relationship between HL and CL in Euphausia distinguenda and E. lamelligera, and the slopes were compared using analysis of covariance (ANCOVA; Zar 1996). All statistical analyses were conducted using Statistica 7.0 software (Stat Soft).

Canonical ordination methods were used to explore multivariate associations of phytoplankton and euphausiid species abundance (per development phase; calyptopis, furcilia, and juveniles + adults) with 9 environmental variables (see Table 5).

Monthly values of the multivariate ENSO index (MEI) and Southern Oscillation index (SOI) (www. esrl.noaa.gov/psd/enso/mei/) were used as proxies to detect the duration and intensity of the 1997-98 El Niño event in the area of study. The daily coastal upwelling index (CUI, $\mathrm{m}^{3} \mathrm{~s}^{-1}$ per $100 \mathrm{~m}$ coastline; Bakun 1973), calculated from the location $21^{\circ} \mathrm{N}, 107^{\circ} \mathrm{W}$, was used to explore the temporal variability of coastal upwelling-downwelling conditions on the day of zooplankton sampling as well as 8 and $15 \mathrm{~d}$ before each sampling event (www.pfel.noaa.gov/ products/products.html). The mixed layer depth (MLD) was estimated as the depth at which the temperature was $1^{\circ} \mathrm{C}$ lower than the temperature at the $10 \mathrm{~m}$ layer. To obtain a proxy of water column stability, a thermal stratification index (TSI) was estimated as the difference between temperature at 10 and $90 \mathrm{~m}$ depth (maximum depth of CTD casts) at each oceanographic station. The monthly anomaly values of TSI were calculated as:

$$
Z_{i j}=X_{i j}-Y_{i}
$$

where $Z_{i j}$ is the TSI anomaly of the $j^{\text {th }}$ month in the $i^{\text {th }}$ year, $X_{i j}$ is the TSI value in the $j^{\text {th }}$ month in the $i^{\text {th }}$ 
year, and $Y_{i}$ is the mean TSI value in the $i^{\text {th }}$ month for the $3 \mathrm{yr}$.

Multivariate statistical analysis was performed using 2 matrices: one with euphausiid abundance per species (columns) and oceanographic stations (rows) and the other with all of the environmental variables (columns) and oceanographic stations (rows; see Table 5). Because Euphausia eximia, E. diomedeae, E. tenera, Stylocheiron affine, and $S$. carinatum were detected only in $<5 \%$ of the zooplankton samples, these species were excluded in the multivariate statistical analysis. Thus, the euphausiid species matrix ( 7 columns $\times 135$ rows) included the 3 most abundant krill species (E. distinguenda, E. lamelligera, and Nematoscelis gracilis) by development phase (larvae and postlarvae) and total euphausiid abundance. To select the most robust canonical analysis, a detrended correspondence analysis of the euphausiid species matrix was used to obtain the length of the environmental gradients (ter Braak \& Prentice 2004). This methodology was also used for the dominant phytoplankon taxa matrix collected during 1998 (30 columns $\times 43$ rows). These gradients were 1.61 for the first axis and $<1.5$ for the rest of the euphausiid matrix axes, and 1.88 for first axis and $<1.2$ for the rest of the phytoplankon matrix axes. We used a linear response model for both matrices. Species-environment relationships were explored using redundancy analysis $\left(\mathrm{RDA}_{i}\right.$ Legendre \& Legendre 1998). For these statistical analyses, scaling was focused on the interspecies euphausiid correlations. Species scores were divided by their correspondent standard deviation and centered by euphausiid species. Forward selection of environmental variables was performed automatically, and statistical significance was calculated using unrestricted Monte Carlo permutation tests.

Environmental matrices of phytoplankton recorded during 1998 ( 7 columns $\times 43$ rows), and euphausiids recorded during 1996 to 1998 (9 columns $\times 135$ rows) were used for the RDA. Tri-plots were used for the representation of the biological variables ordination in the environmental multi-dimensional space (Legendre \& Legendre 1998). All statistical multivariate analyses were performed with the CANOCO software ver. 4.5 (ter Braak \& Šmilauer 2002).

\section{RESULTS}

\section{Oceanographic conditions}

The oceanographic conditions of the 1997-98 El Niño event were first detected in the Cabo Corri- entes region with MEI and SOI proxies in May 1997, and these atmospheric and oceanographic conditions prevailed until June 1998 (Fig. 2A). The daily CUI $\left(\mathrm{m}^{3} \mathrm{~s}^{-1}\right.$ per $100 \mathrm{~m}$ coastline, estimated for the $21^{\circ} \mathrm{N}$, $107^{\circ} \mathrm{W}$ location) showed continuous low-intensity upwelling events between December 1996 and June 1997 and relatively short periods of pronounced downwelling events between July and November of each year (1996-1998; Fig. 2B). Considerable interannual variability was observed, and although the number of days with upwelling events (positive values $>1$ CUI m $\mathrm{s}^{3} \mathrm{~s}^{-1}$ per $100 \mathrm{~m}$ coastline) was similar among years $(86,79$, and $81 \%$ for 1996, 1997, and 1998 , respectively), upwelling intensity $\left(>100 \mathrm{CUI} \mathrm{m}^{3}\right.$ $\mathrm{s}^{-1}$ per $100 \mathrm{~m}$ coastline) was significantly higher during 1998 than during 1996 and 1997 ( $F=13.63$, p < 0.001; Fig. 2B). The number of days with downwelling events (negative values for CUI) was slightly greater during 1997 (20\%) and 1998 (18\%) than during 1996 (12\%), but intensity did not show significant statistical differences.

Vertical distribution of temperature and salinity recorded in the upper $100 \mathrm{~m}$ of the water column also showed clear interannual changes. The MLD was shallow during May to October 1996 ( 24 m), deepening further from the second semester of 1997 to early 1998 (60-80 m), and moderately deep from May to September 1998 (40 m; Fig. 2C). Salinity was typically homogeneous throughout the year (salinities $>34.3$ ), but short periods with low near-surface salinities were associated with the regional hurricane season (July to August; Fig. 2D).

The vertical thermohaline structure also had a strong seasonal pattern (Fig. 2C,D). The temperature from January to May ranged between 14 and $22^{\circ} \mathrm{C}$ with a typical mixed water column, probably associated with intense coastal upwelling activity (Fig. 2B). Episodic downwelling periods occurred between July and October when upwelling events were considerably less intense and temperature ranged between 14 and $31^{\circ} \mathrm{C}$ (Fig. 2B-D).

In 1996, 3 distinct periods for the TSI were distinguished: (1) a period of mixed water column (M) with low average thermal stratification values ( 7 to $10^{\circ} \mathrm{C}$ ), that typically occurred from February to May; (2) a stratified period (S) with higher temperatures $\left(>14^{\circ} \mathrm{C}\right)$, and positive temperature $\left(>2^{\circ} \mathrm{C}\right)$ and salinity anomalies, typically occurring from June to November; and (3) a semi-mixed transitional period (SM) that typically occurred between June and December/January (Fig. 3A,B). During the 1997-98 El Niño event, 3 phases were also detected, which in order of sequence were: El Niño semi-mixed 

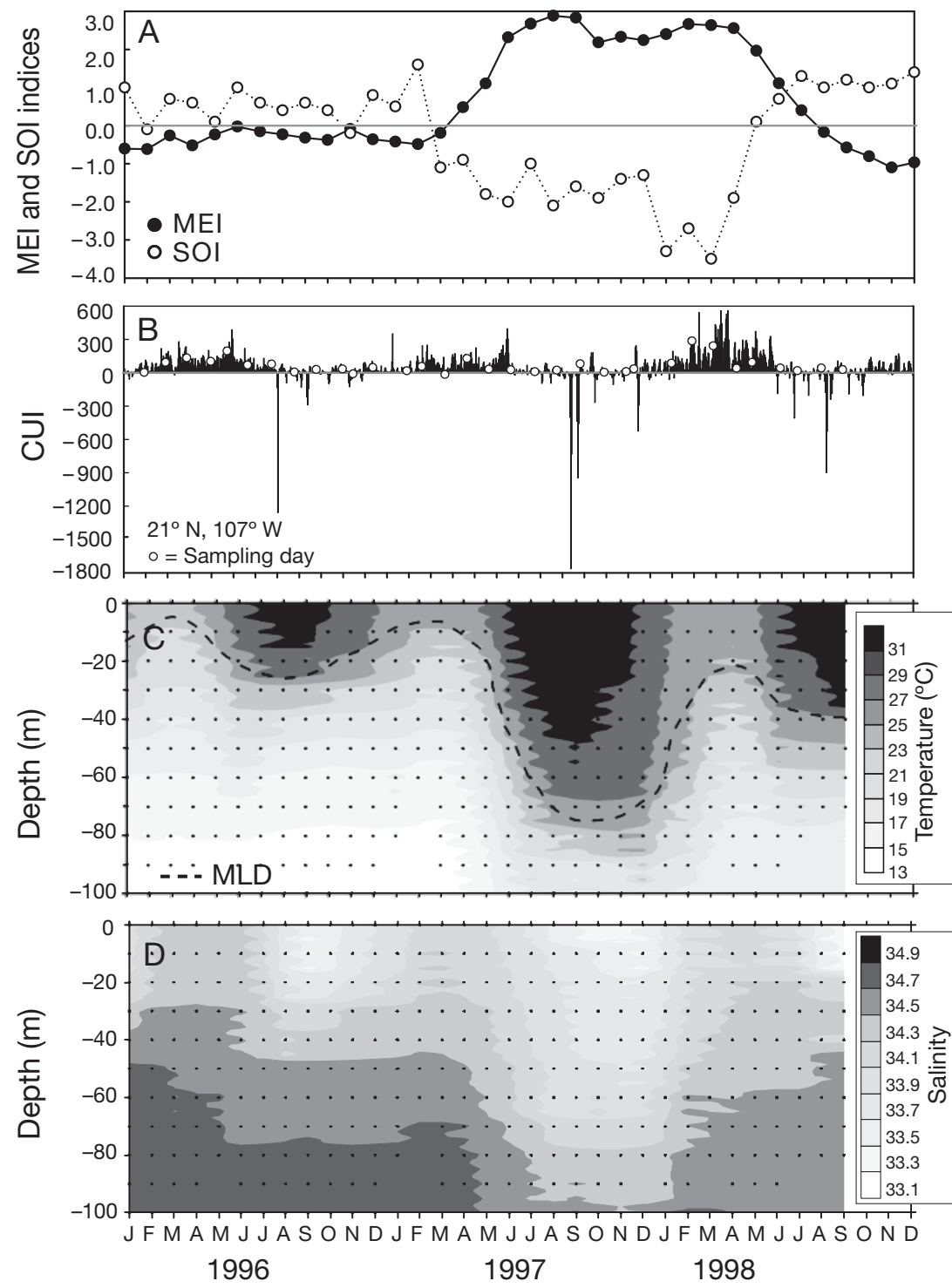

Fig. 2. Time series of environmental and oceanographic conditions recorded during 1996 to 1998 in the Cabo Corrientes region. (A) Multivariate El Niño Southern Oscillation (ENSO) index (MEI) and Southern Oscillation index (SOI) obtained from the US National Oceanic and Atmospheric Administration (NOAA; www.esrl.noaa.gov/psd/data/climateindices/list/). (B) Daily coastal upwelling index (CUI, $\mathrm{m}^{3} \mathrm{~s}^{-1}$ per $100 \mathrm{~m}$ coastline, $21^{\circ} \mathrm{N}, 107^{\circ} \mathrm{W}_{\text {; NOAA }}$ ). (C) Temperature. (D) Salinity. Data in (C) and (D) are the mean values of 6 oceanographic stations sampled along the coast of Jalisco and Colima, Mexico

\section{Seasonal variability of phytoplankton during 1998}

The nano- and microphytoplankton abundances counted from 6 oceanographic stations during 1998 showed 2 significantly distinct seasonal periods (Fig. 4A,B). Diatom abundance was significantly higher from March to May than during the rest of the year $(F=14.442, \mathrm{p}<0.001)$. However, diatom abundance increased moderately during September and December (Fig. 4A). In contrast, dinoflagellates had significantly lower abundances during the $\mathrm{M}$ period than during the $\mathrm{S}$ water column period $(F=$ 11.469, $\mathrm{p}<0.001$ ).

During the 1998 phytoplankton sampling period, 52 nano- and microphytoplankton taxa were identified, including a group of 6 unidentified taxa. Most of the phytoplankton species identified were diatoms from 17 genera $(87 \%$; Table 1). The most common phytoplankton genera were Chaetoceros (10 species), Rhizosolenia (9 species), and Nitzschia (3 species). Thirty species of the genera Rhizosolenia, Chaetoceros, Nitzschia, Leptocylindrus, Ditylum, Thalassiothrix, and Protoperidinium contributed $>98 \%$ of the phytoplankton abundance from the Cabo Corrientes region. Mean cell abundances of 16 diatom species showed significant differences among periods of thermal conditions (Table 1), as did the 6 dominant genera combined $(F=$ 10.690, $\mathrm{p}<0.001$ ). Tukey's test indicated that the mean abundance of Rhizosolenia, Chaetoceros, Nitzschia, and Leptocylindrus tended to increase during the $\mathrm{M}$ period (with intense upwelling events), and mean cell density

(ENSM), El Niño mixed (ENM), and El Niño stratified (ENS) periods. These 3 periods were temporally associated, respectively, with intense upwelling (M), upwelling relaxation (SM), and downwelling (S) periods. A Kruskal-Wallis test indicated that the TSI values of the 3 periods significantly differed from each other $(H=54.41, \mathrm{p}<0.0001)$, which further supported the $\mathrm{M}, \mathrm{SM}$, and $\mathrm{S}$ classification periods (Fig. 3A,B). decreased during SM and S periods $(F=>9.590, \mathrm{p}<$ 0.001 in all cases). Twelve phytoplankton species had significantly higher abundances during the $\mathrm{M}$ period than during the rest of the year. The most abundant phytoplankton species (C. curvisetus, L. danicus, and $R$. stolterforthii) had their peaks of abundance in March, April, and May (M period), drastically decreasing their abundance during the $\mathrm{S}$ and $\mathrm{SM}$ periods (Table 1). The diatoms $D$. brightwellii and $T$. 
Fig. 3. Thermal stratification index (TSI) from January 1996 to December 1998 on the Jalisco and Colima continental shelf. (A) Monthly means $( \pm 95 \%$ confidence intervals); (B) monthly anomaly of TSI after removing the monthly long-term means. Conditions of the water column are indicated as SM: semimixed period; M: mixed period; S: stratified period. Periods under the influence of El Niño are ENSM: El Niño semi-mixed; ENM: El Niño mixed; and ENS: El Niño stratified conditions

fravenfeldii, along with 4 other species, showed a significant increase in abundance during the S and SM periods. The dinoflagellate genus Protoperidinium was absent during the $\mathrm{M}$ period (Table 1) and exhibited considerably high abundance during the SM and $\mathrm{S}$ periods $(F=$ 28.85; $\mathrm{p}<0.05)$.

\section{Seasonal/interannual variability in euphausiid abundance and community composition}

Eight euphausiid species, belonging to 3 genera, were identified during the 1996 to 1998 time series (Table 2). Euphausiid abundance was pooled into 3 developmental phases: (1) calyptopis larvae, (2) furcilia larvae, and (3) postlarvae (juveniles + adults). Euphausiid richness per oceanographic station was typically <3 species, except during the El Niño event (May 1997 to June 1998) when up to 5 species were recorded at the same oceanographic station due to the presence of oceanic species (E. diomedae, E. tenera, Stylocheiron affine, S. carinatum, and Nematoscelis gracilis; Fig. 5A).

Euphausia distinguenda and E. lamelligera were the most abundant euphausiid species during the $3 \mathrm{yr}$, contributing $>97.9 \%$ of the euphausiid abundance in any development phase (Fig. 5B-D). E. distinguenda accounted for 87.8 to $89.5 \%$ of the total euphausiid abundance, having higher postlarval abundance (juveniles + adults) during periods with intense upwelling. High calyptopis and furcilia abundances were consistently associated with SM periods and
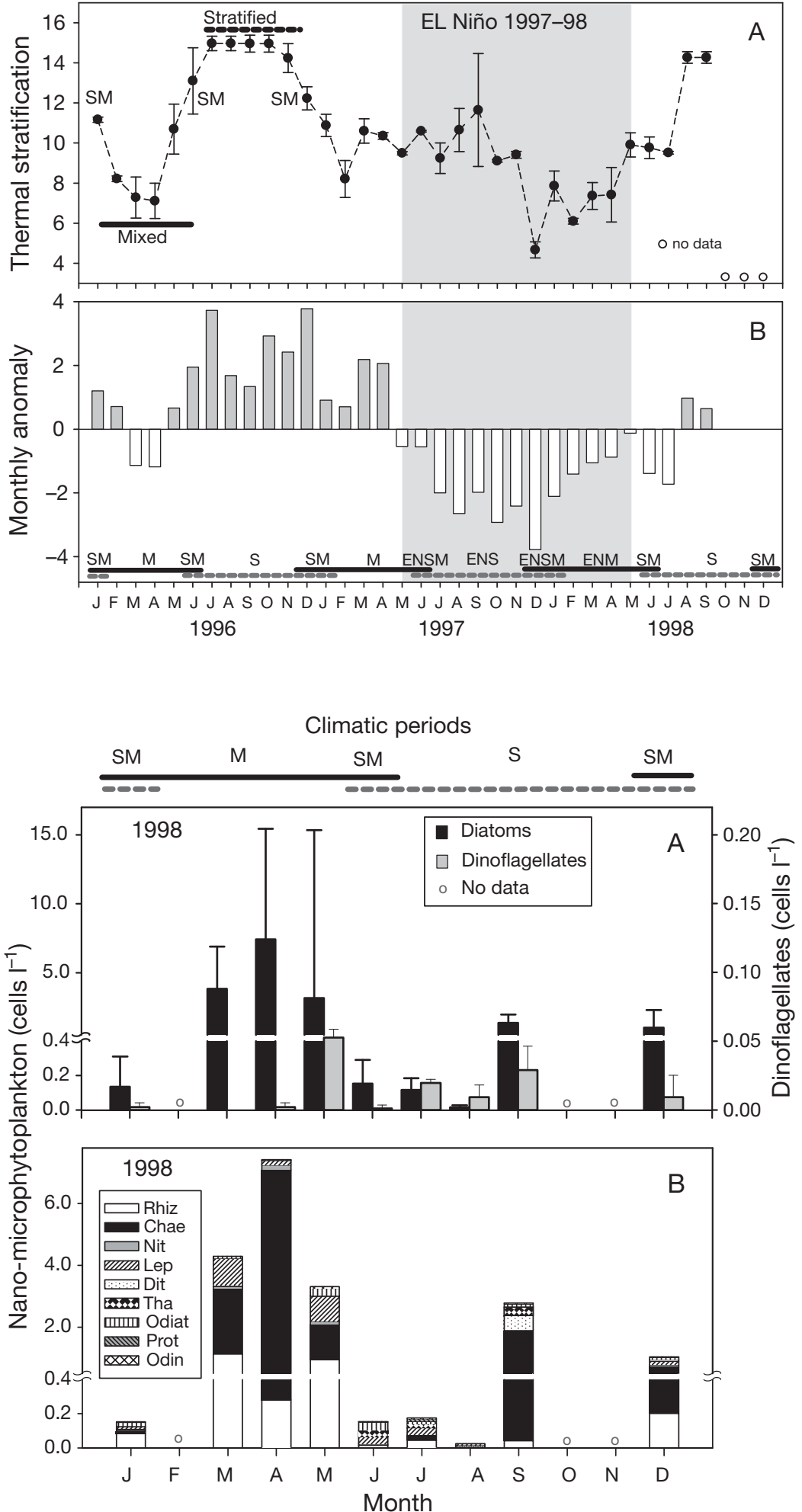

Fig. 4. Monthly mean ( $\pm 95 \%$ confidence interval) of phytoplankton abundance from $10 \mathrm{~m}$ depth detected during 1998: (A) diatoms and dinoflagellates, (B) dominant genera Rhizosolenia (Rhiz), Chaetoceros (Chae), Nitzschia (Nit), Leptocylindrus (Lep), Ditylum (Dit), Thalassiothrix (Tha), other diatoms (Odiat), Protoperidinium (Prot), and other dinoflagellates (Odin). SM, M, and S periods as defined in Fig. 3 
Table 1. Mean and standard deviation (SD) of diatom and dinoflagellate cell abundance (cells $\mathrm{l}^{-1}$ ) per oceanographic period during 1998 off the Cabo Corrientes region, Mexico. Only the most abundant phytoplankton species are shown (the rest of the species were pooled into 'other diatoms' or 'other dinoflagellates'). $\mathrm{n}$ indicates the frequency of the species, i.e. number of samples in which it was found out of the total number of samples analyzed during each period $(15,15$, and 17 for SM, M, and S periods, respectively, as defined in Fig. 3). ANOVA $(F$, p) comparisons among periods with significant results $(\alpha=0.05)$ are shown in bold. Environmental condition abbreviations are as defined in Fig. 3

\begin{tabular}{|c|c|c|c|c|c|c|c|c|c|}
\hline \multirow[t]{2}{*}{ Species } & \multirow[t]{2}{*}{ Code } & \multirow{2}{*}{\multicolumn{2}{|c|}{$\begin{array}{l}\text { Semi-mixed (SM) } \\
\text { Mean } \pm \text { SD (n) }\end{array}$}} & \multicolumn{2}{|l|}{ Mixed (M) } & \multicolumn{2}{|c|}{ Stratified (S) } & \multirow[t]{2}{*}{$F$} & \multirow[t]{2}{*}{$\mathrm{p}$} \\
\hline & & & & Mean \pm SD & (n) & Mean $\pm \mathrm{SD}$ & (n) & & \\
\hline \multicolumn{10}{|l|}{ Diatoms } \\
\hline Chaetoceros atlanticus & Ctla & $11.5 \pm 28.0$ & $(4)$ & $30.0 \pm 46.4$ & $(8)$ & - & $(0)$ & 10.383 & $<0.001$ \\
\hline C. affinis & Caff & $15.7 \pm 46.5$ & (3) & $125.5 \pm 248.3$ & (11) & $13.9 \pm 20.0$ & $(7)$ & 9.234 & $<0.001$ \\
\hline C. brevis & Cbre & - & $(0)$ & $5.1 \pm 19.6$ & (1) & - & $(0)$ & 0.930 & 0.403 \\
\hline C. costatus & $\mathrm{C} \cos$ & $103.0 \pm 231.5$ & (3) & $116.8 \pm 159.6$ & (9) & $109.3 \pm 169.2$ & $(7)$ & 5.137 & 0.010 \\
\hline C. curvisetus & Ccur & $89.2 \pm 218.4$ & (3) & $3464.9 \pm 5452.9$ & (11) & $51.7 \pm 114.8$ & (6) & 14.261 & $<0.001$ \\
\hline C. danicum & Cdan & - & (0) & $3.2 \pm 12.4$ & (1) & - & $(0)$ & 0.930 & 0.403 \\
\hline C. difficilis & Cdif & $0.9 \pm 3.4$ & (1) & - & (0) & - & $(0)$ & 1.488 & 0.238 \\
\hline C. didymus & Cdid & - & $(0)$ & - & $(0)$ & $4.5 \pm 8.9$ & $(4)$ & 3.679 & 0.034 \\
\hline C. messanense & Cmas & - & $(0)$ & - & $(0)$ & $0.4 \pm 1.7$ & (1) & 0.756 & 0.476 \\
\hline C. pelagicus & Cpel & - & $(0)$ & $4.6 \pm 17.8$ & (1) & - & $(0)$ & 0.930 & 0.403 \\
\hline Chaetoceros spp. & Cspp & $1.9 \pm 7.2$ & (1) & - & $(0)$ & - & $(0)$ & 1.488 & 0.238 \\
\hline Ditylum brightwellii & Dbri & $17.1 \pm 36.0$ & $(4)$ & $4.9 \pm 11.0$ & $(4)$ & $158.6 \pm 285.6$ & (6) & 3.918 & 0.028 \\
\hline Leptocylindrus danicus & Ldan & $62.8 \pm 117.1$ & (8) & $568.1 \pm 617.2$ & (13) & $2.5 \pm 4.2$ & (5) & 21.943 & $<0.001$ \\
\hline Nitzschia delicatissima & Ndel & $6.1 \pm 12.7$ & (3) & $84.5 \pm 78.5$ & (12) & $8.2 \pm 21.2$ & $(4)$ & 11.650 & $<0.001$ \\
\hline N. longissima & Nlon & $6.9 \pm 25.0$ & (2) & - & (0) & - & $(0)$ & 1.488 & 0.238 \\
\hline N. pacifica & Npac & $9.7 \pm 25.7$ & (3) & $36.4 \pm 39.1$ & (12) & $3.6 \pm 10.9$ & (2) & 21.513 & $<0.001$ \\
\hline Rhizosolenia alata & Rala & $4.7 \pm 9.0$ & (4) & $6.0 \pm 23.2$ & (1) & $0.4 \pm 1.7$ & (1) & 0.189 & 0.829 \\
\hline$R$. bergonii & Rber & $2.8 \pm 7.8$ & (2) & - & (0) & $5.4 \pm 7.2$ & (8) & 10.108 & $<0.001$ \\
\hline R. calcar avis & Rcal & $4.1 \pm 16.0$ & (1) & $8.8 \pm 27.3$ & (2) & - & $(0)$ & 1.087 & 0.347 \\
\hline R. delicatula & Rdel & $2.3 \pm 5.0$ & (3) & $2.3 \pm 6.2$ & (2) & - & (0) & 1.309 & 0.281 \\
\hline R. fragilissima & Rfra & $2.3 \pm 9.0$ & (1) & $71.5 \pm 95.7$ & (8) & $0.8 \pm 3.4$ & (1) & 8.943 & $<0.001$ \\
\hline R. hebetata & Rheb & - & $(0)$ & - & (0) & $2.1 \pm 4.1$ & $(4)$ & 3.650 & 0.035 \\
\hline R. setigera & Rset & $1.3 \pm 3.6$ & (2) & $24.3 \pm 37.4$ & (8) & $3.7 \pm 5.6$ & (6) & 3.437 & 0.042 \\
\hline R. stolterforthii & Rsto & $102.1 \pm 176.8$ & (9) & $480.3 \pm 627.6$ & (13) & $18.8 \pm 33.2$ & (6) & 12.067 & $<0.001$ \\
\hline$R$. styliformis & Rsty & $1.3 \pm 3.6$ & (2) & $24.6 \pm 34.5$ & (10) & - & $(0)$ & 14.972 & $<0.001$ \\
\hline Thalassiothrix frauenfeldii & Tfra & $22.7 \pm 42.4$ & (5) & $6.0 \pm 13.0$ & (3) & $102.7 \pm 147.6$ & $(10)$ & 4.870 & 0.013 \\
\hline Other diatoms ${ }^{\mathrm{a}}$ & Odiat & $43.8 \pm 54.5$ & (12) & $73.1 \pm 101.4$ & (13) & $35.5 \pm 56.9$ & (12) & 0.902 & 0.413 \\
\hline \multicolumn{10}{|l|}{ Dinoflagellates } \\
\hline Protoperidinium spp. & Pspp & $0.9 \pm 3.6$ & (1) & - & $(0)$ & $15.9 \pm 14.2$ & (14) & 42.547 & $<0.001$ \\
\hline Other dinoflagellates ${ }^{b}$ & Odin & $3.8 \pm 8.8$ & (5) & $11.3 \pm 40.6$ & (3) & $4.9 \pm 5.9$ & (8) & 1.052 & 0.359 \\
\hline \multicolumn{10}{|c|}{$\begin{array}{l}\text { a Asterionella japonica, Biddulphia alternatus, B. cf. alternans, B. longicruris, B. mobilensis, Ceratulina bergonii, Coscinodiscus } \\
\text { centralis, Coscinodiscus lineatus, Coscinodiscus spp., Hemialus sinensis, Navicula spp., Planktoniella sol, Pleurosigma spp., } \\
\text { Prorocentrum gracile, Prorocentrum micans, Protoperidinium spp., Schröderella delicatula, Streptotheca thamesis }\end{array}$} \\
\hline \multicolumn{10}{|c|}{$\begin{array}{l}{ }^{\mathrm{b}} \text { Ceratium furca, Ceratium massilense, Ceratium sp., Ceratium trichoceros, Ceratium tripos, Prorocentrum gracile, Prorocen- } \\
\text { trum micans, Prorocentrum sp. }\end{array}$} \\
\hline
\end{tabular}

with the 1997-98 El Niño. E. lamelligera larvae and postlarvae accounted for 8.4 to $11.9 \%$ of the euphausiid abundance, with higher densities detected during mixed conditions. The rest of the euphausiid species occurred at low abundances $(<2.3 \%)$, but E. tenera and Nematoscelis gracilis were collected at high relative abundances during El Niño winter (December 1997 and January 1998).

Euphausiid abundance and species composition showed considerable seasonal and interannual variability throughout the time series (Fig. 5B-D, Tables 2 \& 3). A post hoc Tukey's test of multiple comparisons revealed that postlarvae total abundance (mainly Euphausia distinguenda and E. lamelligera) were significantly higher during $\mathrm{M}$ periods (geometric means ranged from 1640 to 2430 ind. $1000 \mathrm{~m}^{-3}$ ) than during SM (280 to 1480 ind. $1000 \mathrm{~m}^{-3}$ ) and S periods (270 to 740 ind. $1000 \mathrm{~m}^{-3}$ ). Abundance of oceanic postlarvae (mostly E. tenera and Nematoscelis gracilis) significantly increased during El Niño conditions compared to the rest of the period studied (Tukey's test $\mathrm{p}<0.05$, Table 3 ).

A relatively high percentage of furciliae from 5 oceanic species (Euphausia diomedeae, E. tenera, 
Table 2. Geometric mean abundance of euphausiids (ind. $1000 \mathrm{~m}^{-3}$ ) per developmental stage: calyptopis, furcilia, and postlarvae (juveniles + adults) during periods with distinct environmental conditions recorded during 1996 to $1998 . \mathrm{n}=$ frequency of the species, i.e. number of samples in which it was found out of the total zooplankton samples analyzed in each period (30, 31, 33, 18, 16, and 18 for periods SM, M, S, ENSM, ENM, and ENS, respectively; periods as defined in Fig 3). Euphausiid abundance data were log transformed before the calculation of the mean, and then back-transformed to obtain the geometric mean. ANOVA $(F, \mathrm{p})$ with significant results are shown in bold $(\alpha=0.05)$

\begin{tabular}{|c|c|c|c|c|c|c|c|c|c|}
\hline Species & $\begin{array}{c}\text { SM } \\
\text { Mean (n) }\end{array}$ & $\begin{array}{c}\text { M } \\
\text { Mean (n) }\end{array}$ & $\begin{array}{c}\text { S } \\
\text { Mean (n) }\end{array}$ & $\begin{array}{l}\text { ENSM } \\
\text { Mean (n) }\end{array}$ & $\begin{array}{c}\text { ENM } \\
\text { Mean (n) }\end{array}$ & $\begin{array}{c}\text { ENS } \\
\text { Mean (n) }\end{array}$ & $F$ & $\mathrm{p}$ & $\begin{array}{l}\text { A posteriori contrast } \\
\text { (Tukey's test) }\end{array}$ \\
\hline \multicolumn{10}{|l|}{ Calyptopis } \\
\hline Euphausia distinguend & da $4.6(10)$ & $3.0(7)$ & $5.0(12)$ & $17.4(11)$ & $6.5(5)$ & $2.1(6)$ & 0.96 & 0.23 & \\
\hline E. lamelligera & $1.7(6)$ & $0.4(2)$ & $0.3(2)$ & $0.3(2)$ & $0.6(1)$ & $0.0(0)$ & 1.52 & 0.187 & \\
\hline E. tenera & $0.0(0)$ & $0.0(0)$ & $0.0(0)$ & $0.5(2)$ & $0.0(0)$ & $0.0(0)$ & 2.71 & 0.023 & ENSM>All \\
\hline \multicolumn{10}{|l|}{ Furcilia } \\
\hline E. distinguenda & $139.0(27)$ & $17.8(17)$ & $241.2(27)$ & $101.7(14)$ & $23.3(9)$ & $15.3(10)$ & 4.06 & $<0.001$ & $\mathrm{~S}>\mathrm{M}, \mathrm{S}>\mathrm{ENS}$ \\
\hline E. lamelligera & $11.8(12)$ & $18.2(19)$ & $2.8(8)$ & $6.6(7)$ & $1.9(4)$ & $1.2(3)$ & 2.39 & 0.041 & \\
\hline Nematoscelis gracilis & $0.0(0)$ & $0.0(0)$ & $0.0(0)$ & $19.9(11)$ & $0.8(2)$ & $0.0(0)$ & 26.09 & $<0.001$ & ENSM>All \\
\hline E. diomedeae & $0.0(0)$ & $0.2(2)$ & $0.3(2)$ & $0.0(0)$ & $1.1(3)$ & $1.1(3)$ & 2.07 & 0.073 & \\
\hline E. tenera & $0.22)$ & $0.4(2)$ & $0.4(2)$ & $7.8(8)$ & $0.0(0)$ & $0.0(0)$ & 6.98 & $<0.001$ & ENSM>All \\
\hline E. eximia & $0.0(0)$ & $0.1(1)$ & $0.0(0)$ & $0.0(0)$ & $0.0(0)$ & $0.0(0)$ & 0.73 & 0.600 & \\
\hline Stylocheiron affine & $0.0(0)$ & $0.0(0)$ & $0.1(1)$ & $0.2(1)$ & $0.4(2)$ & $0.0(0)$ & 1.34 & 0.252 & \\
\hline S. carinatum & $0.0(0)$ & $0.0(0)$ & $0.0(0)$ & $0.0(0)$ & $0.4(1)$ & $0.2(1)$ & 1.50 & 0.193 & \\
\hline \multicolumn{10}{|l|}{ Postlarva } \\
\hline E. distinguenda & $735.6(29)$ & $512.8(29)$ & $155.9(27)$ & $167.6(16)$ & $1006.2(14)$ & $93.0(12)$ & 3.25 & $<0.001$ & \\
\hline E. lamelligera & $58.7(19)$ & $256.2(25)$ & $6.1(12)$ & $9.2(9)$ & $216.6(12)$ & $41.2(11)$ & 5.81 & $<0.001$ & $\mathrm{M}>\mathrm{S}, \mathrm{M}>\mathrm{ENSM}, \mathrm{ENM}>\mathrm{S}$ \\
\hline N. gracilis & $0.1(1)$ & $0.0(0)$ & $0.0(0)$ & $13.1(12)$ & $0.0(0)$ & $0.0(0)$ & 37.15 & $<0.001$ & ENSM $>$ All \\
\hline E. diomedeae & $0.2(2)$ & $0.1(1)$ & $0.2(2)$ & $0.0(0)$ & $0.0(0)$ & $0.7(2)$ & 1.64 & 0.153 & \\
\hline E. tenera & $0.0(0)$ & $0.0(0)$ & $0.2(2)$ & $0.6(3)$ & $0.0(0)$ & $0.0(0)$ & 2.52 & 0.033 & $\mathrm{ENSM}>\mathrm{SM}, \mathrm{ENSM}>\mathrm{M}$ \\
\hline E. eximia & $0.0(0)$ & $0.0(0)$ & $0.0(0)$ & $0.2(1)$ & $0.0(0)$ & $0.0(0)$ & 1.48 & 0.199 & \\
\hline S. affine & $0.1(1)$ & $0.4(3)$ & $0.3(3)$ & $0.3(1)$ & $0.8(2)$ & $0.0(0)$ & 0.98 & 0.433 & \\
\hline S. carinatum & $0.2(1)$ & $0.0(0)$ & $0.1(1)$ & $0.0(0)$ & $1.2(2)$ & $0.4(2)$ & 2.00 & 0.082 & \\
\hline
\end{tabular}

Stylocheiron affine, S. carinatum, and Nematoscelis gracilis) invaded the neritic environment of the Cabo Corrientes region during the 1997-98 El Niño event (Table 3). With the re-establishment of typical oceanographic conditions during July 1998, the abundance of these 5 species decreased significantly $(p<0.05)$ or they were absent. A similar trend was observed with $N$. gracilis juvenile and adult abundance. In contrast, both calyptopis and furcilia phases of E. lamelligera, as well as total furciliae abundance, showed a significant decrease during the 1997-98 El Niño period (Table 3).

\section{Phytoplankton and euphausiid species relationships with environmental conditions}

The RDA of phytoplankton and euphausiid species as a function of the environmental conditions showed a clear separation of the $\mathrm{M}, \mathrm{S}$, and SM periods (Fig. 6). The 3 RDA canonical ordination axes explained $41.1 \%$ of the total variance for phytoplankton species in the multidimensional environmental space with significant correlation in axis 1 $(F=14.19, \mathrm{p}<0.001 ;$ and $F=4.42, \mathrm{p}<0.001$ for all axes). The species-environment relationship explained $88 \%$ of the total variance (Table 4 ). The first RDA axis showed the highest positive correlation with CUI and a negative correlation with $10 \mathrm{~m}$ depth temperature, MLD, and TSI prevailing during the M period (upwelling season). The first RDA axis had a strong positive correlation with 17 numerically dominant phytoplankton species, particularly with Chaetoceros curvisetus, C. atlanticus, C. affinis, Leptocylindrus danicus, Nitzschia delicatissima, N. pacifica, Rhizosolenia stolterforthii, $R$. styliformis, and $R$. fragilissima (Table 1, Fig. 6A). The second axis was mainly associated with the TSI (Table 4 ). The CUI on the sampling day and CUI $8 \mathrm{~d}$ before sampling had a relatively weak and negative correlation with the second axis. All of these sample units were associated with the strong $\mathrm{S}$ period (downwelling season). Ditylum brightwellii, Thalassiothrix frauenfeldii, C. didymus, $R$. bergonii, $R$. hebetata, and Protoperidinium spp. were strongly associated with the second axis environmental gradient (Fig. 6A, Table 1).

Three clusters of oceanographic stations were identified in the RDA plot of euphausiid species per development phase in the oceanographic stations space (Fig. 6B). Stations sampled during the $\mathrm{M}$ 

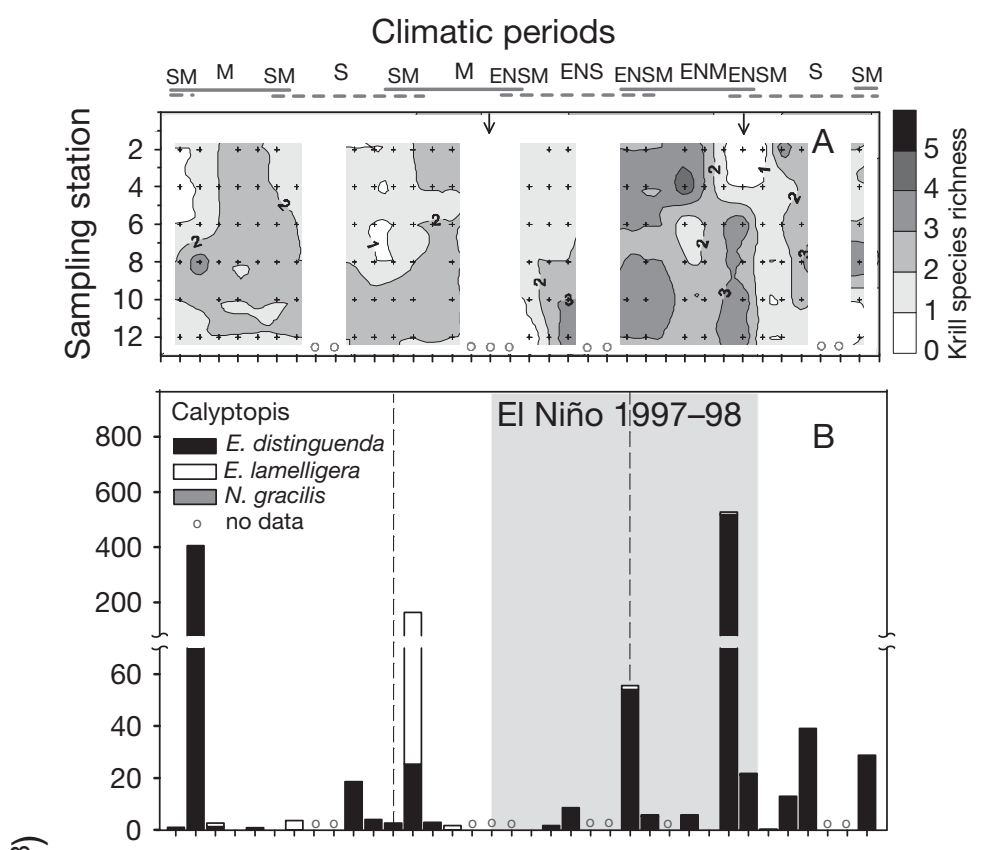

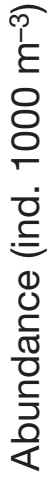

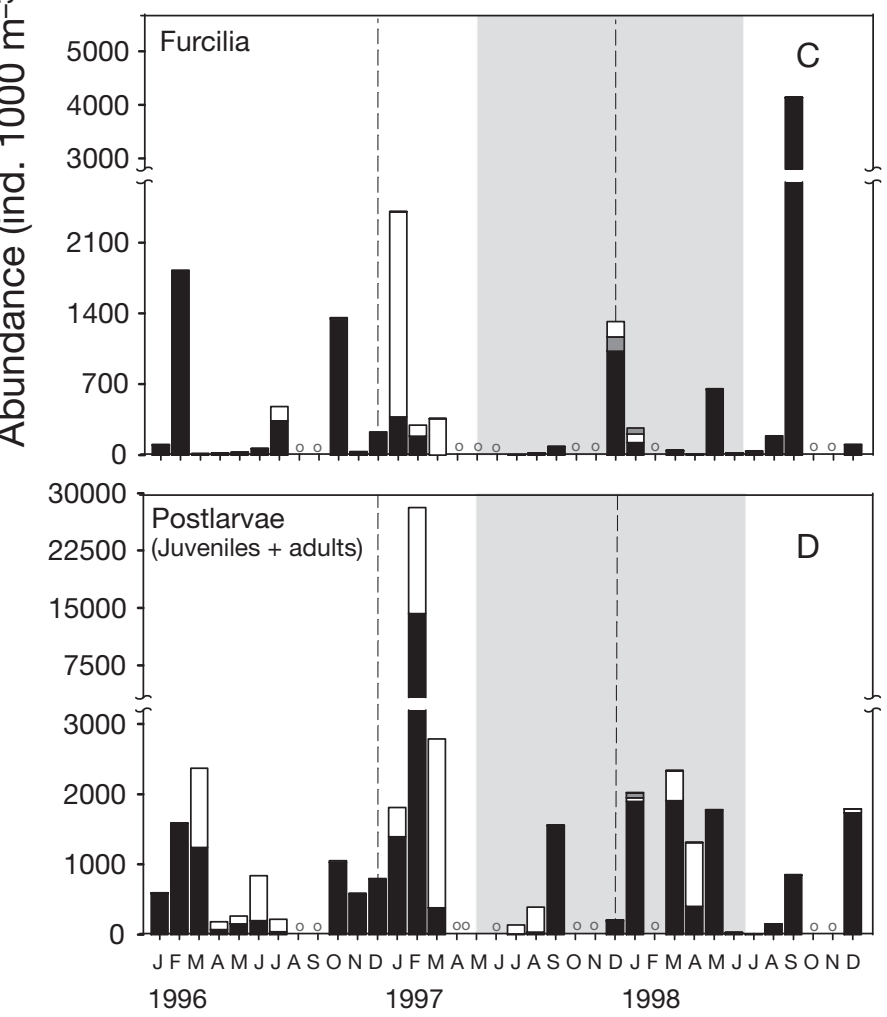

Fig. 5. Euphausiid species richness and abundance (ind. $1000 \mathrm{~m}^{-3}$ ) along the Jalisco and Colima coasts collected during 1996 to 1998: (A) monthly latitude changes of euphausiid species richness, (B-D) monthly geometric stacked abundance means of the 3 most abundant euphausiid species (Euphausia distinguenda, E. lamelligera, and Nematoscelis gracilis) per life phases: (B) calyptopis larvae, (C) furcilia larvae, and (D) postlarvae. The period under the influence of the 1997-98 El Niño event is delimited with arrows in (A) and the gray area in (C-D). SM, M, and S conditions as defined in Fig. 3 period were clustered mainly on the right side of horizontal axis 1, significantly associated with CUI at $8 \mathrm{~d}$ before the sampling date. Stations sampled during the short $\mathrm{S}$ periods were clustered mainly on the upper left side of this axis and positively associated with vectors of $10 \mathrm{~m}$ temperature and MLD. Central sampling stations represented those sampled during the SM period (semi-mixed water column). Euphausiid abundance was principally affected by seasonal variability in stratification conditions, being particularly abundant during the $\mathrm{M}$ period.

The first 2 RDA axes explained $25 \%$ of the total variance for euphausiid species abundance with significant correlation in axis 1 $(F=21.06, \mathrm{p}<0.001)$ and for all axes $(F=5.99$, $\mathrm{p}<0.001$ ); while $83 \%$ of the variance was explained in the species-environment relationship (Table 5). The first RDA axis had high correlations with $10 \mathrm{~m}$ salinity, CUI (monthly), CUI at $15 \mathrm{~d}$ before sampling, and a negative correlation with $10 \mathrm{~m}$ temperature. Total euphausiid and Euphausia distinguenda and E. lamelligera postlarvae abundances were significantly correlated with the first axis environmental gradient. This result indicates that they had high abundance associated with low temperature, and relatively high salinity and phytoplankton cell abundance (Fig. 6B). The second axis explained $10.5 \%$ of species variability and $35 \%$ of the species-environment relationship, showing a positive correlation with temperature and a negative correlation with CUI at $8 \mathrm{~d}$ before sampling and also with CUI on the respective sampling day. Only E. distinguenda and Nematoscelis gracilis larvae were strongly associated with the second axis environmental gradient (Fig. 6B). The second axis gradient reflects oligotrophic conditions that prevailed during the $\mathrm{S}$ period and the tropical influence of El Niño.

\section{Sex ratio, biometry, and HSI}

The mean seasonal variability of adult Euphausia distinguenda and E. lamelligera sex ratio, TL, CL, and HSI showed different responses during each environmental period (Figs. $7 \&$ 8). Mean sex ratio was close to $50 \%$ throughout most of the time series except during periods of mixed water column conditions 
Table 3. Comparison of interannual euphausiid abundance (ind. $1000 \mathrm{~m}^{-3}$ ) per developmental stage: calyptopis, furcilia, and postlarvae (juveniles + adults) from a period with near the mean environmental conditions (May 1996 to May 1997) versus a period with the 1997-98 El Niño event (June 1997 to May 1998). $\mathrm{n}$ = number of samples in which a species was found out of the total number of zooplankton samples analyzed for each year ( 49 samples for both years). Abundance data were $\left(\log _{10}[x+1]\right)$ transformed before the calculation of the mean, and then back-transformed to obtain the geometric mean. Only life phases with significant results are shown $(\alpha=0.05)$

\begin{tabular}{|lrrrrrr|}
\hline Species & $\begin{array}{c}\text { Typical } \\
\text { mean }\end{array}$ & $\mathrm{n}$ & $\begin{array}{c}\text { El Niño } \\
\text { mean }\end{array}$ & $\mathrm{n}$ & $F$ & $\mathrm{p}$ \\
\hline Calyptopis & & & & & & \\
Euphausia lamelligera & 14.1 & 9 & 2.7 & 3 & 4.23 & 0.042 \\
$\begin{array}{l}\text { Furcilia } \\
\text { E. lamelligera }\end{array}$ & 273.2 & 29 & 26.8 & 14 & 12.94 & $<0.001$ \\
Nematoscelis gracilis & 0.0 & 0 & 24.2 & 13 & 15.54 & $<0.001$ \\
E. diomedeae & 0.5 & 1 & 6.2 & 6 & 4.89 & 0.029 \\
Postlarvae & & & & & & 0.003 \\
N. gracilis & 0.4 & 1 & 15.0 & 12 & 5.86 & 0.003 \\
\hline
\end{tabular}

cantly higher during the $\mathrm{M}$ and SM periods than during the $\mathrm{S}$ period (Fig. 7D).

Both sexes of Euphausia distinguenda and E. lamelligera had significantly lower HL and HSI during the S and ENS periods than during the rest of the study period (Fig. 7 E-H). CL explained between 19 and $55 \%$ of the HL variability throughout the study period (Fig. 8A,B). E. distinguenda and E. lamelligera showed a statistically significant linear regression of the $\mathrm{HL}$ as a function of the CL having significant distinct slopes during $M, S M$, and S periods $(F=62.79$ for $E$. distinguenda and 26.02 for E. lamelligera, $\mathrm{p}<0.001$; ANCOVA). This statistical test indicates that the HL of euphausiids collected during the most productive seasons ( $\mathrm{M}$ and $\mathrm{SM}$ ) were larger than the mean HL of euphausiid specimens col-

(M and ENM), when the female proportion of both species increased (Fig. 7A,B). The male E. distinguenda total body length significantly decreased after the M period from 11.9 to $10.5 \mathrm{~mm}$ in specimens collected during the ENS period (Fig. 7C). E. lamelligera male and female total body length was signifi- lected during $\mathrm{S}$ periods, when the lowest phytoplankton cell abundance was measured. Thus, these seasonal environmental differences, in terms of mixed-stratified column water conditions, seem to be moderately associated with euphausiid sex ratio and TL, and highly associated with the HSI variability.
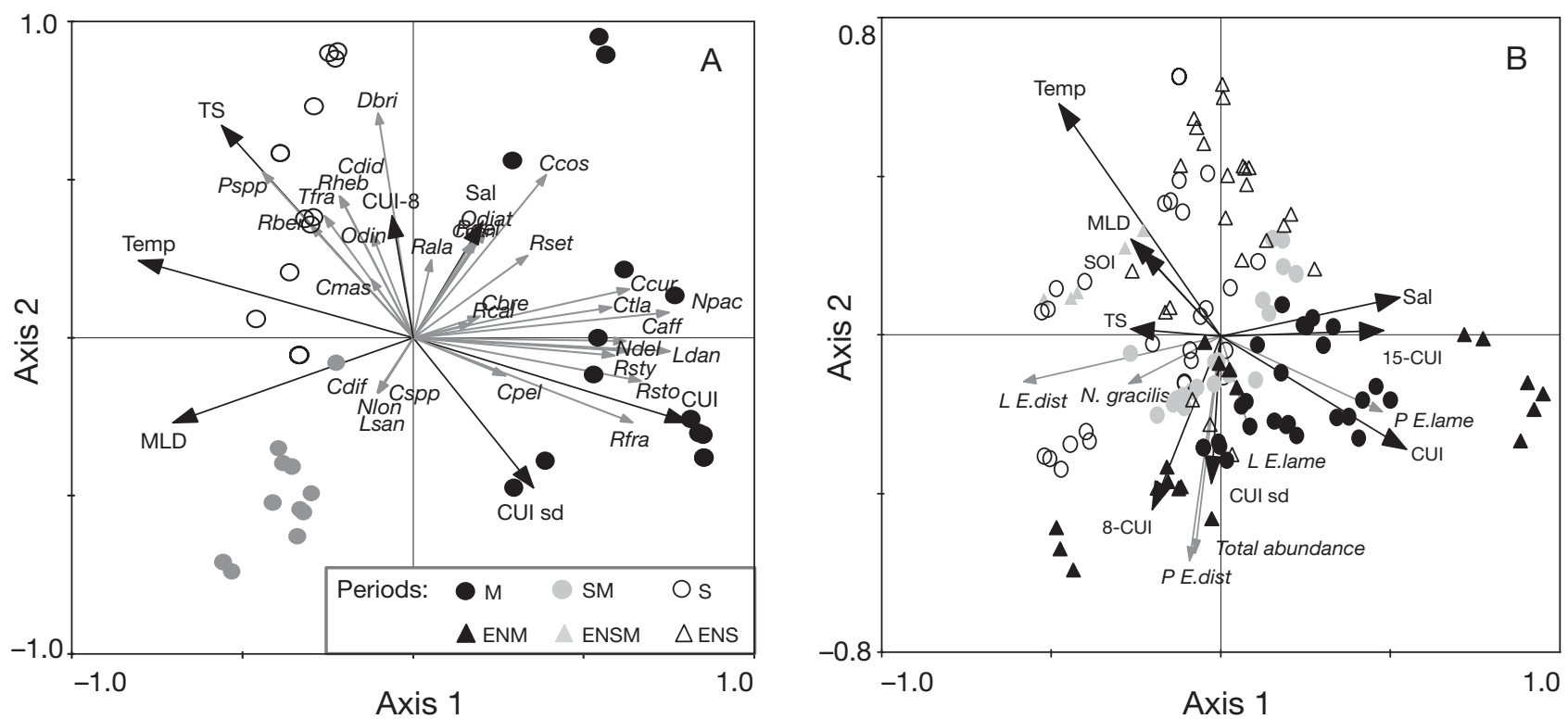

Fig. 6. Redundancy analysis triplot showing the correspondence between environmental variables (black lines) and the most abundant species (gray lines) of (A) phytoplankon and (B) euphausiids. Symbols are oceanographic stations classified by vertical stratification of the water column as defined in Fig. 3. The length of vectors indicates the magnitude of explained variability for each species. Phytoplankon species codes as in Table 1. Euphausiid species are: Euphausia distinguenda (E. dist), E. lamelligera (E. lame), and Nematoscelis gracilis ( N. gracilis). The letter L before the name means larvae (calyptopis + furcilia) and P means postlarvae (juveniles + adults). Abbreviations of the enviromental variables are: thermal stratification index (TSI), mixed layer depth (MLD), $10 \mathrm{~m}$ depth temperature (Temp), $10 \mathrm{~m}$ salinity (Sal), Southern Oscillation Index (SOI), coastal upwelling index (CUI) on the sampling day (CUI sd), CUI 8 d before sampling (8-CUI), and CUI 15 d before sampling (15-CUI) 
Table 4. Summary of the redundancy analysis (RDA) using 7 environmental variables and abundances of 30 phytoplankton species collected at 43 oceanographic stations sampled during 1998. Significant correlations $(\alpha=0.05)$ with each environmental variable and the RDA axes are indicated with asterisks. CUI: coastal upwelling index

\begin{tabular}{|lccc|}
\hline Ordination axes & 1 & 2 & 3 \\
\hline Eigenvalues & 0.288 & 0.093 & 0.029 \\
$\begin{array}{l}\text { Species-environment } \\
\quad \text { correlations }\end{array}$ & 0.862 & 0.699 & 0.737 \\
Cumulative variance (\%) & & & \\
$\quad$ Species & 28.8 & 38.1 & 41.1 \\
$\quad$ Species-environment & 61.5 & 81.3 & 87.6 \\
$\quad$ relation & & & \\
Inter-set correlations of environmental & & \\
variables with species axes & & & \\
$\quad$ Thermal stratification & $-0.561^{*}$ & $0.671^{*}$ & -0.041 \\
$\quad$ 10 m temperature & $-0.805^{*}$ & 0.244 & -0.353 \\
$\quad$ 10 m salinity & 0.203 & 0.365 & 0.093 \\
Mixed layer depth & $-0.704^{*}$ & -0.270 & -0.014 \\
CUI (monthly) & $0.809^{*}$ & -0.268 & 0.224 \\
CUI on sampling day & 0.353 & $-0.475^{*}$ & $-0.326^{*}$ \\
CUI 8 d before sampling & -0.062 & $-0.385^{*}$ & $-0.450^{*}$ \\
\hline
\end{tabular}

\section{DISCUSSION}

We demonstrated that tropical euphausiid species inhabiting a coastal region of the ETP are sensitive to seasonal changes of upwelling-downwelling variability and interannual climatic-oceanographic perturbations (like El Niño) as are euphausiid species of higher latitudes distributed in subtropical and temperate ecosystems. Those changes were evident in: (1) euphausiid species composition, which was more diverse during the El Niño event with the invasion of oceanic species toward the neritic environment, (2) euphausiid abundance, which was greater during the upwelling season (M period) than during the transitional (SM period) and downwelling (S period) seasons, and (3) body condition and trophic status, indicated by the HSI, which was significantly higher during the $\mathrm{M}$ and SM periods than during the $\mathrm{S}$ period. Thus, a dynamic perspective emerges from the analysis of this relatively short time series in a tropical Mexican ecosystem that is, to our knowledge, one of the few multi-year systematic time series done in tropical latitudes (Mackas \& Beaugrand 2010).

\section{Changes in the oceanographic conditions and phytoplankton}

The seasonal variability of the thermohaline vertical column water structure off the Cabo Corrientes
Table 5. Summary of the redundancy analysis (RDA) using 9 environmental variables and the abundances of the most abundant euphausiid species collected from 135 stations obtained during 1996 to 1998. Significant correlations ( $\alpha=$ 0.05 ) with each environmental variable and the RDA axes are indicated with asterisks. SOI: Southern Oscillation index, CUI: coastal upwelling index

\begin{tabular}{|lccc|}
\hline Ordination axes & 1 & 2 & 3 \\
\hline Eigenvalues & 0.144 & 0.105 & 0.032 \\
Species-environment & 0.63 & 0.584 & 0.762 \\
$\quad$ correlations & & & \\
Cumulative variance (\%) & 14.4 & 25 & 28.2 \\
$\quad$ Species & 47.8 & 82.8 & 93.5 \\
$\quad$ Species-environment & & \\
$\quad$ relation & & & \\
Inter-set correlations of environmental & & \\
variables with species axes & & & \\
$\quad$ Thermal stratification & -0.266 & 0.019 & $-0.700^{*}$ \\
$\quad$ 10 m temperature & $-0.478^{*}$ & $0.590^{*}$ & 0.002 \\
$\quad 10$ m salinity & $0.528^{*}$ & 0.100 & -0.366 \\
Mixed layer depth & -0.265 & 0.248 & $0.548^{*}$ \\
SOI & -0.235 & 0.219 & $-0.647^{*}$ \\
CUI (monthly) & $0.547^{*}$ & -0.285 & 0.287 \\
CUI on sampling day & -0.027 & $-0.372^{*}$ & $0.506^{*}$ \\
CUI 8 d before sampling & -0.202 & $-0.438^{*}$ & 0.010 \\
CUI 15 d before sampling & $0.479^{*}$ & 0.016 & 0.211 \\
\hline
\end{tabular}

coastal region had a strong influence during the 1997-98 El Niño event (Fig. 2). On the seasonal time scale, we demonstrated that between February and early June, the upper water column (surface to $40 \mathrm{~m}$ depth) was considerably colder, saltier, mixed, and with a shallower MLD than during the rest of the year, indicating the influence of intense upwelling activity during this period (Figs. 2C,D \& 3). López-Sandoval et al. (2009a,b) reported maximum surface chl a concentration $\left(>2 \mathrm{mg} \mathrm{m}^{-3}\right.$ ) and higher mean primary productivity rates $\left(447 \mathrm{mg} \mathrm{C} \mathrm{m}^{2} \mathrm{~d}^{1}\right.$ ) between February and June corresponding to $\mathrm{M}$ and SM periods off Cabo Corrientes. In the context of our results, it seems that the abundance of euphausiids in the Cabo Corrientes region is predominantly bottom-up controlled. Recent studies also have shown evidence of this bottom-up control in the Cabo Corrientes region in phytoplankton (Cepeda-Morales et al. 2009), ichthyoplankton (LeónChávez et al. 2010), and yellowfin tuna (TorresOrozco et al. 2005).

The cessation of winds or decreasing wind intensity caused downwelling events that led to strong nearsurface thermal stratification from early July to November and induced significant changes in phytoplankton and euphausiid abundance and species composition. During S periods, surface waters near the coast tended to deepen the thermocline $(>28 \mathrm{~m})$ 


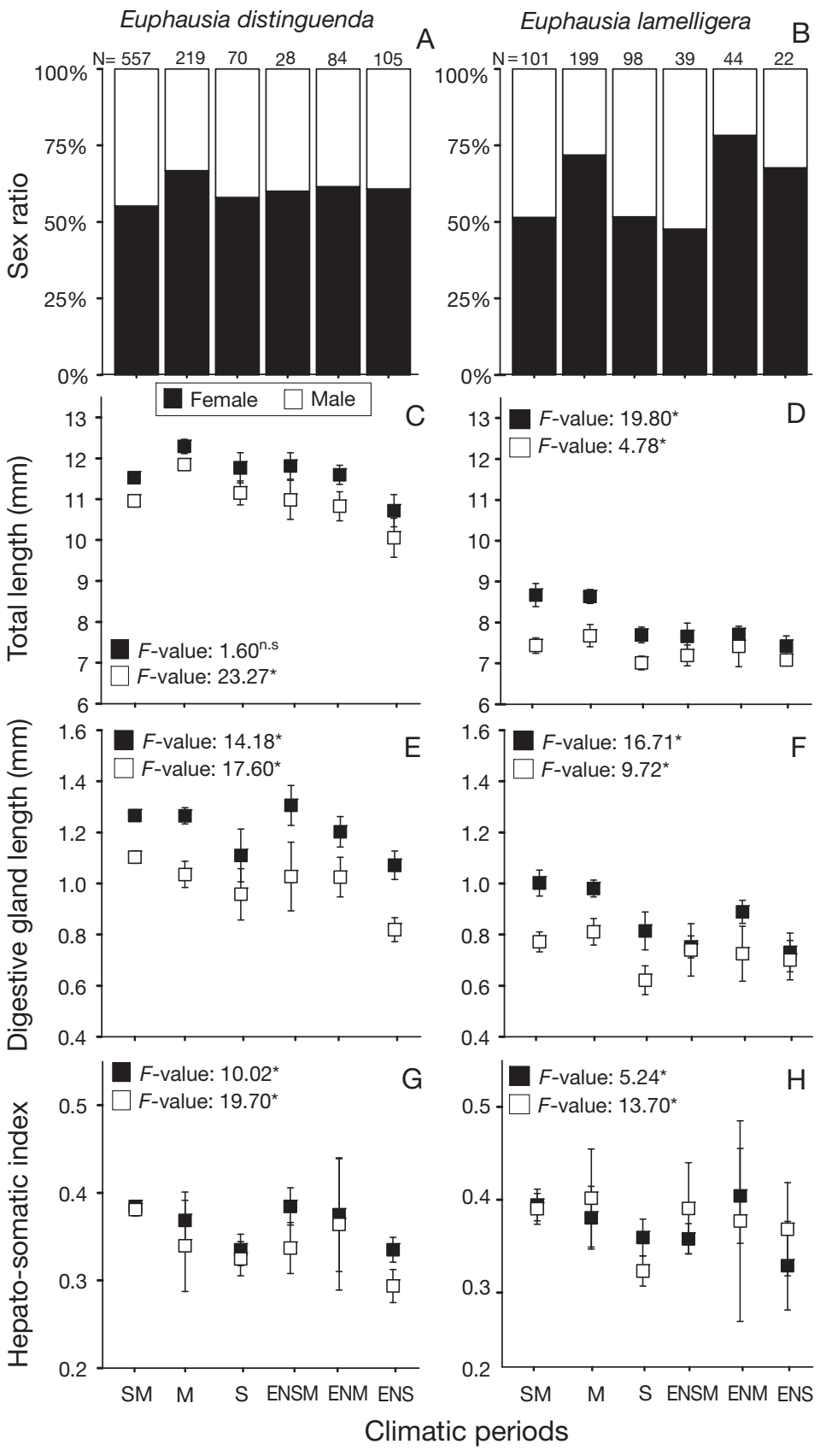

Fig. 7. Euphausia distinguenda and E. lamelligera. Seasonal variability of $(A, B)$ sex ratio, $(C, D)$ total length, $(E, F)$ hepatopancreas length, and $(\mathrm{G}, \mathrm{H})$ hepato-somatic index (HSI) of $E$. distinguenda $(\mathrm{A}, \mathrm{C}, \mathrm{E}, \mathrm{G})$ and E. lamelligera (B, D, F, H) adults. Means ( $\pm 95 \%$ confidence intervals) per oceanographic periods as defined in Fig. 3. Results of ANOVA among periods are shown, indicating significance at $\mathrm{p}<0.001\left(^{*}\right)$; ns: not significant. $\mathrm{N}=$ number of adult specimens measured during each sampling period

and therefore the mixed layer. In the Cabo Corrientes region, minimum phytoplankton biomass and phytoplankton production rates occur during a short downwelling period (July to November; López Sandoval et al. 2009a,b). We suggest that the strong thermohaline seasonal variability in the upper water column of the neritic zone off Cabo Corrientes is mostly controlled by upwelling/ downwelling variability, atmosphere- ocean net heat flux, and freshwater input caused by rain/hurricane seasons (which increases precipitation and river discharges). Other meso-scale processes like eddies, fronts, and filaments may also induce significant changes in the upper layers (Lavín et al. 2006, Cepeda-Morales et al. 2009, Godínez et al. 2010, León-Chávez et al. 2010, Martínez-Flores et al. 2011).

On the interannual time scale, the most conspicuous environmental changes in the upper $100 \mathrm{~m}$ layer were caused by thermodynamic anomalies imposed by the El Niño of 1997-98. In June 1997, the first environmental signal of El Niño conditions was detected as a stronger seasonal variation induced by winds that increased upwelling activity between January and June 1998 (Fig. 2). The main environmental changes resulting from the 1997-98 El Niño event were the increase in surface temperature promoting pronounced changes in thermal stratification (homogeneously warm) and the deepening of the MLD (>60 m). These changes in environmental patterns were caused by strong onshore advection of the Tropical Surface Water and Pacific Equatorial Superficial Water in the upper 90 m layer, an oceanographic response previously documented in the Cabo Corrientes region during this El Niño event (Filonov \& Tereshchenko 2000). Surprisingly, during January to June 1998, upwelling conditions prevailed and the typically strong seasonal variability rapidly damped the 1997-98 El Niño event effect. The diatoms Chaetoceros curvisetus, Leptocylindrus danicus, and Rhizosolenia stolterforthii were positively associated with this comparatively high productivity cold-water period. Thus, intense upwelling events induced an increase in abundance of these 3 diatom species (and other species) and characterized this brief but intense 1997-98 El Niño event (Fig. 4D,E). Similarly, the plankton biomass (chl a concentration and zooplankton biomass) off the Baja California Peninsula $\left(32-24^{\circ} \mathrm{N}\right)$ was not considerably affected during the 1997-98 El Niño along the west coast of the Baja California peninsula (Lavaniegos et al. 2002). Contrary to our results, previous studies in the central 


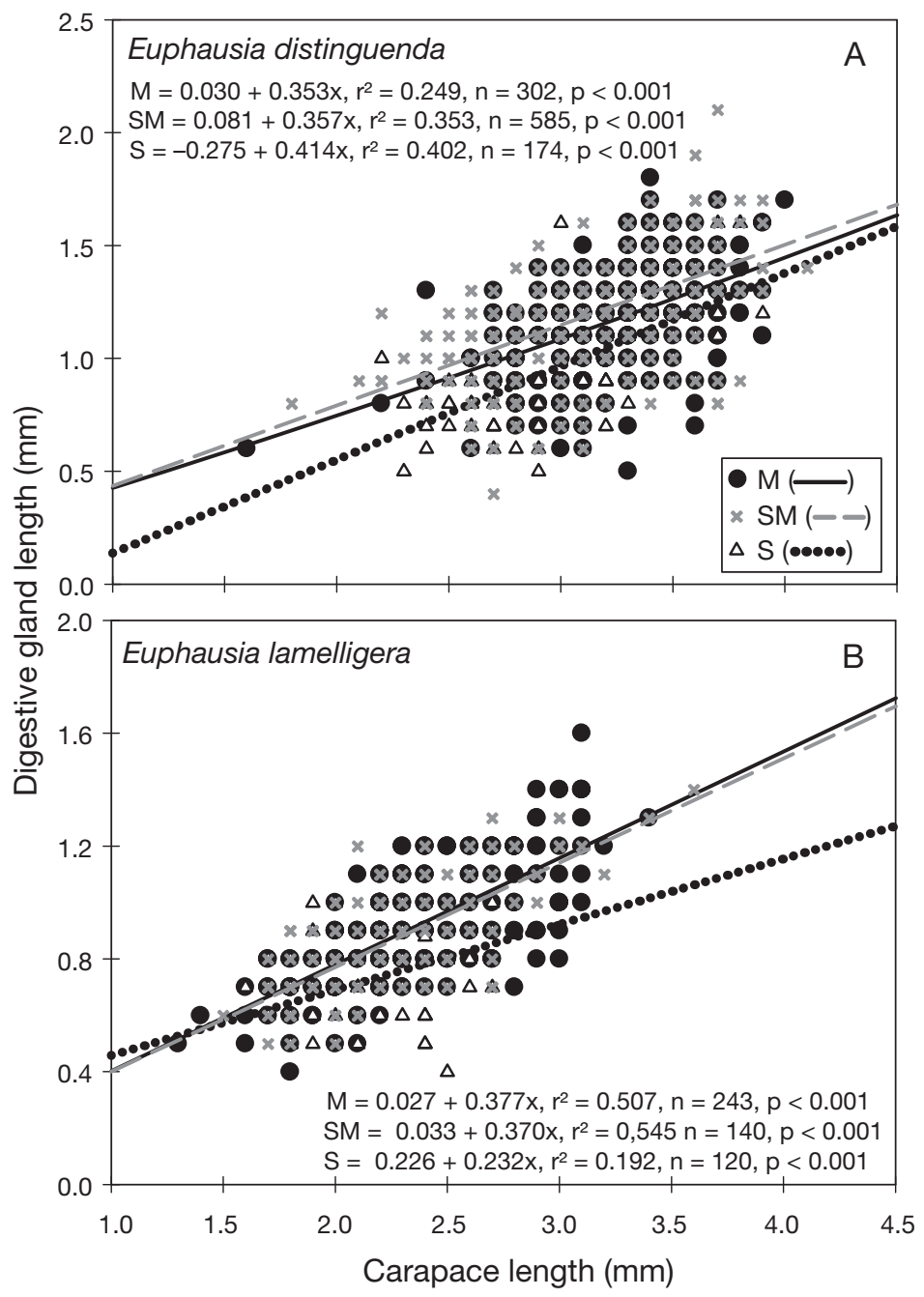

Fig. 8. Euphausia distinguenda and E. lamelligera. Linear regression model of the hepatopancreas length as a function of the carapace length from specimens collected during $M, S M$, and S periods (as defined in Fig. 3) for (A) E. distinguenda and (B) E. lamelligera

Mexican Pacific reported that the variability in the upper layer is mostly dominated by El Niño-induced anticyclonic circulation (Lavín et al. 2006, Godínez et al. 2010) and decreasing primary production (Chavez et al. 1999). Barber \& Chavez (1983) suggested that inshore ecosystems are significantly less affected by El Niño events than offshore ecosystems, as may happen at the Cabo Corrientes region.

\section{Seasonal/interannual variability of tropical euphausiids}

We show evidence of strong seasonal variability of euphausiid abundance and relatively moderate 1996 to 1998 interannual changes in euphausiid community structure and relatively low species diversity. Although the Mexican central Pacific is a tropical ecosystem with a relatively shallow oxygen minimum zone (Wyrtki 1967, Seibel 2011), the highest density of total euphausiid abundance occurred during the intense upwelling season (February to May). These seasonal changes were of the same order of magnitude as that reported in other upwelling regions of the Mexican sector of the California Current System. However, this tropical ecosystem has overall lower euphausiid biomass because most tropical species are considerably smaller $(<13 \mathrm{~mm}$ TL) than subtropical and temperate species in the California Current (up to $25 \mathrm{~mm} \mathrm{TL}$; Brinton 1962, 1979, Lavaniegos 1994, 1995, Gómez-Gutiérrez 1995, 1996, Gómez-Gutiérrez et al. 1995, Brinton \& Townsend 2003) and the Gulf of California (Brinton \& Townsend 1980, Lavaniegos et al. 1989). Euphausiid abundance showed a strong seasonal cycle imposed by the 2 small-sized dominant tropical euphausiid species (Euphausia distinguenda TL $<13 \mathrm{~mm}$ and E. lamelligera TL $<9 \mathrm{~mm}$ Fig. 5B-D). Multivariate analysis (RDA) confirmed that euphausiid abundance in this tropical coastal ecosystem was closely related to seasonal patterns of nano- and microphytoplankton abundance driven by upwelling-transitiondownwelling ( $\mathrm{M}, \mathrm{SM}$, and $\mathrm{S})$ conditions. Samples collected between February and May were positively correlated with CUI on the sampling day, and those collected between July and November were negatively correlated with CUI (Fig. 6, Table 5). The RDA demonstrated that seasonal variability of euphausiid abundance and community structure was of a larger magnitude than the interannual variability during the period studied. This seasonal pattern corresponded with the phytoplankton species composition and abundance. Franco-Gordo et al. (2004) included 12 sampling stations, in the same region, during a period of 3 yr (December 1995 to December 1998) of zooplankton biomass and fish larvae abundance and species composition. They reported that the highest zooplankton biomass and ichthyoplankton abundance occurred from January to May (period of intense upwelling events) every year. This pattern confirms that strong seasonal variability of windinduced coastal upwelling events imposes a bottomup control on merozooplankton and holozooplankton abundance and biomass in the southern Cabo Corrientes region (Fig. 2B). 
The 8 euphausiid species detected during the 1996 to 1998 time series in the Mexican central Pacific have been previously reported in multiple oceanographic cruises carried out in the ETP region (Brinton 1962, 1979, Sánchez-Osuna \& Hendrickx 1983, GómezGutiérrez \& Hernández-Trujillo 1994, Färber-Lorda et al. 2010). All of these previous offshore studies have reported that the neritic species Euphausia lamelligera is the numerically dominant euphausiid species of this tropical region. However, we detected that during 1996 to 1998, E. distinguenda was consistently the most abundant euphausiid species of the coastal region off the Cabo Corrientes region (100-130 m seafloor depth; Fig. 5B-D, Table 3).

In the Gulf of Tehuantepec, low Euphausia distinguenda larval abundance was recorded onshore from 25 oceanographic stations sampled in January 1989, suggesting that the coastal zone is not within its optimal reproductive area and/or distribution range for this species (Färber-Lorda et al. 1994). In the Cabo Corrientes region, the maximum larval abundance of $E$. distinguenda was detected during SM periods and during the 1997-98 El Niño event, suggesting onshore transport because this species is typically more abundant in offshore waters (FärberLorda et al. 2010). E. distinguenda had exceptional peaks of postlarval abundance during $M$ periods (Fig. 5B-D). Thus, oceanographic conditions that prevailed along the Jalisco and Colima continental shelf were favorable for the E. distinguenda population, reported here for the first time as a numerically dominant species in a neritic region of the ETP. In fact, the RDA showed that E. distinguenda postlarvae increased their abundance and probably their reproduction (indicated by presence of calyptopis and mature adults) during active upwelling when phytoplankton abundance and chl a concentration reached their highest levels (López Sandoval et al. 2009a,b). The neritic E. lamelligera postlarvae were also abundant during the intense upwelling period having a strong positive correlation with CUI (Fig. 6B). Considering the relatively high proportion of larvae and adults of E. distinguenda and E. lamelligera, we propose that this coastal upwelling region is a relevant reproduction area for both krill species. This maximum abundance of euphausiids and reproduction periods showed a clear association with upwelling variability as reported in euphausiid species distributed at coastal zones of the Eastern Boundary Current upwelling ecosystems of California (Dorman et al. 2005), Humboldt (Riquelme-Bugueño et al. 2012), and Benguela (Barange \& Stuart 1991, Pillar et al. 1992).
The euphausiid species richness considerably increased with the presence of larvae and juveniles of oceanic species such as Euphausia diomedeae, E. tenera, Stylocheiron affine, S. carinatum, and Nematoscelis gracilis during the 1997-98 El Niño period (Fig. 5). This increase in species richness may indicate strong onshore advection of Tropical Surface Water and Subsurface Equatorial Water previously reported for this region (Filonov \& Tereshchenko 2000). RDA showed that the temperature explained most of the euphausiid variability pattern of $N$. gracilis, supporting the idea of an onshore advection of warm water, indicated by the deepening of the thermocline, was likely the process that transported and even caused favorable conditions for proliferation of this tropical oceanic species assemblage along the continental shelf of Cabo Corrientes. A similar response to the 1997-98 El Niño was reported in the southern region of the California Current System where higher abundance of 3 unusual tropical species (E. distiguenda, E. tenera, and mainly E. eximia) along the west coast of the Baja California peninsula (Ambriz-Arreola 2007) and northward advection of the subtropical neritic species Nyctiphanes simplex in waters from California to Canada (Brodeur 1986, Mackas \& Galbraith 2002, Marinovic et al. 2002, Peterson et al. 2002, Tanasichuk \& Cooper 2002, Feinberg \& Peterson 2003, Keister et al. 2005). These species were indicators of strong onshore and poleward flow of warm water forced by different El Niño events.

\section{Other evidence of the upwelling effects on Euphausia distinguenda and E. lamelligera}

HL and the HSI were useful indicators of seasonal krill trophic condition, showing significantly higher HSI values during the $\mathrm{M}$ and SM periods (when phytoplankton peaked) than during $\mathrm{S}$ periods (when phytoplankton had their lowest values; Fig. 7). The hepatopancreas of crustaceans serves the dual role of secreting enzymes and absorbing digested food. Specifically, the hepatopancreas assists in the depolymerization of $(1 \rightarrow 3)-\beta$-D-glucans in the euphausiid diet (McConville et al. 1986), being a sensitive indicator of recent and long-term trophic conditions of Euphausia superba (Endo \& Kadoya 1991, Shin 2000, Virtue et al. 2010, O'Brien et al. 2011) and E. crystallorophias (Nicol et al. 2004) in Antarctic ecosystems. These studies demonstrated that HL of these polar krill species was strongly associated with the seasonal and inter-annual variability in food 
abundance or dietary shifts. Our results suggest that tropical euphausiids are also sensitive to seasonal changes in food availability.

The sex ratio of Euphausia distinguenda and $E$. lamelligera was typically close to 50:50 throughout the 1996 to 1998 time series. However, the decrease in the proportion of males during column water $\mathrm{M}$ periods suggests that both species are exposed to different predation rates or that males and females have distinct vertical migration patterns when the ratio departs from 50:50 (Fig. $7 \mathrm{~A}, \mathrm{~B}$ ). In Antarctic krill, it was demonstrated that males grow faster but die younger than females (Kawaguchi et al. 2007), and this pattern might also hold for tropical species under mixed column water conditions. Tarling (2003) mentioned that selective mortality, either through physiological differences between sexes or sex-specific predation, is the major factor responsible for the substantial sex ratio variability in Meganyctiphanes norvegica. Hill et al. (1996) also found evidence that males of E. superba in the northwest of South Georgia evade nets and predators such as macaroni penguins Eudyptes chrysolophus more efficiently than females. These studies provide insight into explaining possible mechanisms of departure from standard sex ratios in the Cabo Corrientes region. A closer examination of top-down control processes alongside studies of the physiological capacity of tropical krill are also required to gain a fuller understanding of the operation of this tropical ecosystem.

In conclusion, we provide evidence that temporal variability in upwelling/downwelling is a key coastal mechanism in the seasonal regulation of euphausiid species composition, abundance, and likely the plankton productivity of this tropical ecosystem. We also demonstrate that seasonal upwelling-downwelling variability in Cabo Corrientes forced a larger bottom-up influence than the 1997-98 El Niño conditions. Our study will provide baseline information for future work focused on the comparisons among zooplankton time series from different ocean regions that, according to Mackas \& Beaugrand (2010), will represent a critical step to predict the likely amplitude and steepness of future climate changes in marine ecosystems.

Acknowledgements. Research funds were provided by the University of Guadalajara. Consejo Nacional de Ciencias y Tecnología (CONACyT) provided a doctoral graduate grant to I.A.A. We thank 3 anonymous reviewers for their valuable comments and E. Kozak for English editorial help on an earlier version of the manuscript. All authors except I.A.A. are Sistema Nacional de Investigadores (SNI) fellows.

\section{LITERATURE CITED}

Álvarez-Borrego S (1983) Gulf of California. In: Ketchum BH (ed) Estuaries and enclosed seas. Elsevier, Amsterdam, p 427-449

Ambriz-Arreola I (2007) Multivariate study of the euphausiid communities from the southern sector of the California Current during the 1997-99 ENSO cycle. MS thesis, Centro de Investigación Científica y de Educación Superior de Ensenada (in Spanish)

Bakun A (1973) Coastal upwelling indices, west coast of North America 1946-71. NOAA Techn Rep SSRF-671

Barange M, Stuart V (1991) Distribution patterns, abundance and population dynamics of the euphausiids $\mathrm{Nyc}-$ tiphanes capensis and Euphausia hanseni in the northern Benguela upwelling system. Mar Biol 109:93-101

Barber RT, Chavez FP (1983) Biological consequences of El Niño. Science 222:1203-1210

Baumgartner TR, Christensen N Jr (1985) Coupling of the Gulf of California to large-scale interannual climatic variability. J Mar Res 43:825-848

Brinton E (1962) The distribution of Pacific euphausiids. Bull Scripps Inst Oceanogr Univ Calif 8:51-270

Brinton E (1979) Parameters relating to the distribution of planktonic organisms, especially euphausiids in the Eastern Tropical Pacific. Prog Oceanogr 8:125-189

Brinton E (1981) Euphausiid distributions in the California Current during the warm winter-spring of 1977-1978, in the context of a 1949-1966 time series. Calif Coop Ocean Fish Invest Rep 22:135-154

Brinton E (1996) Euphausiacea. In: Gasca R, Suárez E (eds) Introducción al estudio del zooplancton marino. ECOSUR/CONACYT, Chetumal, p 297-341

Brinton E, Townsend A (1980) Euphausiids in the Gulf of California - The 1957 cruises. Calif Coop Ocean Fish Invest Rep 21:211-236

Brinton E, Townsend A (2003) Decadal variability in abundances of the dominant euphausiid species in southern sectors of the California Current. Deep-Sea Res II 50: 2449-2472

Brinton E, Fleminger A, Siegel-Causey D (1986) The temperate and tropical planktonic biotas of the Gulf of California. Calif Coop Ocean Fish Invest Rep 27:228-266

Brinton E, Ohman MD, Townsend AW, Knight MD, Bridgeman AL (2000) Euphausiids of the world ocean. World Biodiversity Database CD-ROM Series. Expert Center for Taxonomic Identification, Amsterdam

$>$ Brodeur R (1986) Northward displacement of the euphausiid Nyctiphanes simplex Hansen to Oregon and Washington waters following the El Niño event (1982-83). J Crustac Biol 6:686-692

Cepeda-Morales J, Beier E, Gaxiola-Castro G, Lavín MF, Godínez VM (2009) Effects of the oxygen minimum zone on the second chlorophyll maximum in the Eastern Tropical Pacific off Mexico. Cienc Mar 35:389-403

> Chavez FP, Strutton PG, Friederich GE, Feely RA, Feldman GC, Foley DG, McPhaden MJ (1999) Biological and chemical response of the equatorial Pacific Ocean to the 1997-98 El Niño. Science 286:2126-2131

Cupp EE (1943) Marine plankton diatoms of the west coast of North America. Bull Scripps Inst Oceanogr Univ Calif $1: 1-238$

> Dorman JG, Bollens SM, Slaughter AM (2005) Population biology of euphausiids off northern California and effects of short time-scale wind events on Euphausia pacifica. 
Mar Ecol Prog Ser 288:183-198

Endo Y, Kadoya N (1991) Colorimetry of the hepatopancreas in Antarctic krill, Euphausia superba. Polar Biol 11: 135-137

Färber-Lorda J, Lavin MF, Zapatero MA, Robles JM (1994) Distribution and abundance of euphausiids in the Gulf of Tehuantepec during wind forcing. Deep-Sea Res 41: 359-367

Färber-Lorda J, Trasviña A, Cortés-Verdín P (2010) Summer distribution of euphausiids in the entrance of the Sea of Cortés in relation to hydrography. Deep-Sea Res II 57: 631-641

> Feinberg LR, Peterson WT (2003) Variability in duration and intensity of euphausiid spawning off central Oregon. Prog Oceanogr 57:363-379

Fernández-Álamo MA, Färber-Lorda J (2006) Zooplankton and the oceanography of the Eastern Tropical Pacific: a review. Prog Oceanogr 69:318-359

Filonov AE, Tereshchenko IE (2000) El Niño 1997-98 monitoring in mixed layer at the Pacific Ocean near Mexico's West Coast. Geophys Res Lett 27:705-707

Franco-Gordo C, Godínez-Domínguez E, Suárez-Morales E (2002) Larval fish assemblages off the central Pacific coast of Mexico. J Plankton Res 24:775-784

Franco-Gordo C, Godínez-Domínguez E, Filonov AE, Tereshchenko IE, Freire J (2004) Plankton biomass and larval fish abundance prior to and during the El Niño period of 1997-98 along the central Pacific coast of México. Prog Oceanogr 63:99-123

Godínez VM, Beier E, Lavín MF, Kurezyn JA (2010) Circulation at the entrance of the Gulf of California from satellite altimeter and hydrographic observations. J Geophys Res 115:C04007

Gómez-Gutiérrez J (1995) Distribution patterns, abundance and population dynamics of the euphausiids Nyctiphanes simplex and Euphausia eximia in the west coast of Baja California, Mexico. Mar Ecol Prog Ser 119:63-76

Gómez-Gutiérrez J (1996) Ecology of early larval development of Nyctiphanes simplex Hansen (Euphausiacea) off the southwest coast of Baja California, Mexico. Bull Mar Sci 58:131-146

Gómez-Gutiérrez J, Hernández-Trujillo S (1994) Euphausiacea and Copepoda of the oceanic front off Cabo San Lucas B.C.S., México, in August of 1988. Rev Biol Trop 42:155-164

Gómez-Gutiérrez J, Palomares-García R, Gendron D (1995) Community structure of the euphausiid populations along the west coast of Baja California, Mexico, during the weak ENSO 1986-1987. Mar Ecol Prog Ser 120: $41-51$

Gómez-Gutiérrez J, Peterson WT, Miller CB (2005) Crossshelf life-stage segregation and community structure of the euphausiids off central Oregon (1970-1972). DeepSea Res II 52:289-315

Gómez-Gutiérrez J, Ambriz-Arreola I, Castellanos-Osorio I, De Silva-Dávila R and others (2009) Biology and ecology of subtropical euphausiids: research from Mexico. Workshop D, Krill biology and ecology in the world's oceans. 3rd and final International GLOBEC Open Science: marine ecosystems: from function to prediction, Victoria, British Columbia, June 22-26, 2009, p 96

Hasle GR (1978) Using the inverted microscope. In: Sournia A (ed) Phytoplankton manual. UNESCO, Paris, p 191-196

Hill HJ, Trathan PN, Croxall JP, Watkins JL (1996) A comparison of Antarctic krill Euphausia superba caught by nets and taken by macaroni penguins Eudyptes chrysolophus: evidence for selection? Mar Ecol Prog Ser 140: $1-11$

> Huyer A (1983) Coastal upwelling in the California Current system. Prog Oceanogr 12:259-284

Kawaguchi S, Finley LA, Jarman S, Candy SG and others (2007) Male krill grow fast and die young. Mar Ecol Prog Ser 345:199-210

Keister JE, Johnson TB, Morgan CA, Peterson WT (2005) Biological indicators of the timing and direction of warm-water advection during the 1997/1998 El Niño off the central Oregon coast, USA. Mar Ecol Prog Ser 295: 43-48

Keister JE, Cowles TJ, Peterson WT, Morgan CA (2009) Do upwelling filaments result in predictable biological distributions in coastal upwelling ecosystems? Prog Oceanogr 83:303-313

> Kessler WS (2006) The circulation of the Eastern Tropical Pacific: a review. Prog Oceanogr 69:181-217

$>$ Lavaniegos BE (1994) Dispersion and development patterns in larvae of Nyctiphanes simplex (Euphausiacea) in the upwelling region off Baja California. Mar Ecol Prog Ser 106:207-225

> Lavaniegos BE (1995) Production of Nyctiphanes simplex in Vizcaino Bay, western Baja California. J Crustac Biol 15: 444-453

Lavaniegos BE, Ambriz-Arreola I (in press) Interannual variability in krill off Baja California in the period 1997-2005. Prog Oceanogr doi: 10.1016/j.pocean.2011.11.008

Lavaniegos BE, Lara-Lara JR, Brinton E (1989) Effects of the 1982-83 El Niño event on the euphausiid populations of the Gulf of California. Calif Coop Ocean Fish Invest Rep 30:73-85

Lavaniegos BE, Jimenez-Perez LC, Gaxiola-Castro G (2002) Plankton response to El Niño 1997-1998 and La Niña 1999 in the southern region of the California Current. Prog Oceanogr 54:33-58

> Lavín MF, Beier E, Gómez-Valdés J, Godínez VM, García J (2006) On the summer poleward coastal current off SW México. Geophys Res Lett 33:L02601

Legendre P, Legendre L (1998) Numerical ecology, 2nd English edn. Elsevier, Amsterdam

> León-Chávez CA, Sánchez-Velasco L, Beier E, Lavín MF, Godínez VM, Färber-Lorda J (2010) Larval fish assemblages and circulation in the Eastern Tropical Pacific in autumn and winter. J Plankton Res 32:397-410

Licea-Durán S (1974) Sistemática y distribución de diatomeas de la Laguna de Agiabampo, Son./Sin., Mexico. Ann Inst Cienc Mar Limnol 1:99-157

López-Sandoval DC, Lara-Lara JR, Álvarez-Borrego S (2009a) Phytoplankton production by remote sensing in the region off Cabo Corrientes, Mexico. Hidrobiológica 19:185-192

López-Sandoval DC, Lara-Lara JR, Lavín MF, ÁlvarezBorrego S, Gaxiola-Castro G (2009b) Primary productivity observations in the Eastern Tropical Pacific off Cabo Corrientes, Mexico. Cienc Mar 35:169-182

> Mackas DL, Beaugrand G (2010) Comparisons of zooplankton time series. J Mar Syst 79:286-304

> Mackas DL, Galbraith M (2002) Zooplankton community composition along the inner portion of Line P during the 1997-1998 El Niño event. Prog Oceanogr 54:423-437

> Mackas DL, Thomson RE, Galbraith M (2001) Changes in the zooplankton community of the British Columbia continental margin, 1985-1999, and their covariation with 
oceanographic conditions. Can J Fish Aquat Sci 58: 685-702

Marinovic BB, Croll DA, Gong N, Benson SR, Chavez FP (2002) Effects of the 1997-1999 El Niño and La Niña events on zooplankton abundance and euphausiid community composition within the Monterrey Bay coastal upwelling system. Prog Oceanogr 54:265-277

Martínez-Flores G, Nava-Sánchez EH, Zaitzev O (2011) Remote sensing of suspended matter plumes triggered by runoff in the south Gulf of California. Oceánides 26: 1-18 (In Spanish)

Mauchline J, Fisher L (1969) The biology of euphausiids. Adv Mar Biol 7:1-454

McConville MJ, Ikeda T, Bacic A, Clarke AE (1986) Digestive carbohydrases from the hepatopancreas of two Antarctic euphausiid species (Euphausia superba and E. crystallorophias). Mar Biol 90:371-378

Nicol S, Virtue P, King R, Davenport SR, McGaffin AF, Nichols P (2004) Condition of Euphausia crystallorophias off East Antarctica in winter in comparison to other seasons. Deep-Sea Res II 51:2215-2224

O'Brien CO, Virtue P, Kawaguchi S, Nichols PD (2011) Aspects of krill growth and condition during late winter-early spring off East Antarctica $\left(110-130^{\circ}\right.$ E). DeepSea Res II 58:1211-1221

Pesantes F (1978) Dinoflagelados del fitoplancton del Golfo de Guayaquil. Publ Inst Oceanogr Armada Ecuador Cienc Mar Biol 2:1-98

Peterson WT, Keister JE, Feinberg LR (2002) The effects of the 1997-1998 El Niño/La Niña events on hydrography and zooplankton off the central Oregon coast. Prog Oceanogr 54:381-398

Pillar SC, Stuart V, Barage M, Gibbons MJ (1992) Community structure and trophic ecology of euphausiids in the Benguela ecosystem. S Afr J Mar Sci 12:393-409

Riquelme-Bugueño R, Nuñez S, Jorquera E, Valenzuela L, Escribano R, Hormazábal S (2012) The influence of upwelling variation on the spatially-structured euphausiid community off central-southern Chile in 2007-2008. Prog Oceanogr 92-95:146-165

Roden GI (1964) Oceanographic aspects of the Gulf of California. Marine geology of the Gulf of California. Am Assoc Pet Geol Bull 3:30-58

Sánchez-Osuna L, Hendrickx ME (1983) Resultados de las campañas SIPCO (sur de Sinaloa, México) a bordo del B/O 'El Puma'. Abundancia y distribución de los Euphausiacea (Crustacea: Eucarida). Ann Inst Cienc Mar Limnol 11:99-106

Saunders RP, Glenn AD (1969) Diatoms. Mem Hourglass Cruises 2:1-251

Editorial responsibility: Marsh Youngbluth,

Fort Pierce, Florida, USA
Shin HC (2000) Condition indicators for Antarctic krill, Euphausia superba. PhD thesis, University of Tasmania, Hobart

Seibel B (2011) Critical oxygen levels and metabolic suppression in oceanic oxygen minimum zones. J Exp Biol 214:326-336

Smith EP, Richardson SL (1977) Standard techniques for pelagic fish egg and larvae surveys. FAO Fish Tech Pap No. 175, Rome

Sournia A (1967) Le genre Ceratium (Péridinien plantonique) dans le canal de Mozambique. Contributión á une révision mondiale. Vie Milieu 18:375-499

Sournia A, Grall JR, Jaques G (1979) Diatomées et dinoflagellés planctoniques d'une coupe méridienne dans le sud de l'océan Indien (campagne 'Antiprod I' du MarionDufresne, mars 1977). Bot Mar 22:183-198

Steidinger KA, Williams J (1970) Dinoflagellates. Mem Hourglass Cruises 2:1-251

Suárez-Morales E, Franco-Gordo C, Saucedo-Lozano M (2000) On the copepod community of the central Mexican tropical Pacific (autumn, 1990). Crustaceana 73: 751-761

Tanasichuk RW, Cooper C (2002) A northern extension of the range of the euphausiid Nyctiphanes simplex into Canadian waters. J Crustac Biol 22:206-209

Tarling GA (2003) Sex-dependent diel vertical migration in northern krill Meganyctiphanes norvegica and its consequences for population dynamics. Mar Ecol Prog Ser 260: 173-188

Taylor FVR (1976) Dinoflagellates from the International Indian Ocean Expedition. A report on material collected by the RV 'Anton Bruun' 1963-1964. Bibl Bot 132:1-234

ter Braak CJF, Prentice IC (2004) A theory of gradient analysis. Adv Ecol Res 34:236-282

ter Braak CJF, Šmilauer P (2002) Canoco reference manual and CanoDraw for Windows user's guide: software for canonical community ordination. Version 4.5. Microcomputer power, Ithaca, NY

Torres-Orozco E, Trasviña A, Muhlia-Melo A, OrtegaGarcía S (2005) Mesoscale dynamics and yellowfin tuna catches in the Mexican Pacific. Cienc Mar 31:671-683

Virtue P, Kawaguchi S, McIvor J, Nicol S and others (2010) Krill growth and condition in Western Indian Ocean sector of the Southern Ocean $30-80^{\circ} \mathrm{E}$ in austral summer 2006. Deep-Sea Res II 57:948-955

Wyrtki K (1967) Circulation and water masses in the Eastern Equatorial Pacific Ocean. Int $\mathrm{J}$ Oceanol Limnol 1: $117-147$

Zar J (1996) Biostatistical analysis, 3rd edn. Prentice Hall, Upper Saddle River, NJ

Submitted: June 30, 2011; Accepted: January 13, 2012

Proofs received from author(s): March 28, 2012 